\title{
The Contribution of Environmental Siting and Permitting Requirements to the Cost of Energy for Wave Energy Devices
}

Reference Model \#5
AE Copping
SH Geerlofs
LA Hanna

June 2014

Pacific Northwest

NATIONAL LABORATORY

Proudly Operated by Battelle Since 1965 


\section{DISCLAIMER}

This report was prepared as an account of work sponsored by an agency of the United States Ciovernment. Neither the United States Ciovernment nor any agency thereof, nor Battelle Memorial Institute, nor any of their employees, makes any warranty, express or implied, or assumes any legal liability or responsibility for the aceuracy, completeness, or usefulness of any information, apparatus, product, or process disclosed, or represents that its use would not infringe privately owned rights. Reference herein to any specific commercial product, process, or service by trade name, trademark, manufacturer, or otherwise does not necessarily constitute or imply its endorsement, recommendation, or favoring by the United States Government or any agency thereof, or Battelle Memorial Institute. The views and opinions of authors expressed herein do not necessarily state or reflect those of the United States (jovernment or any agency thereof.

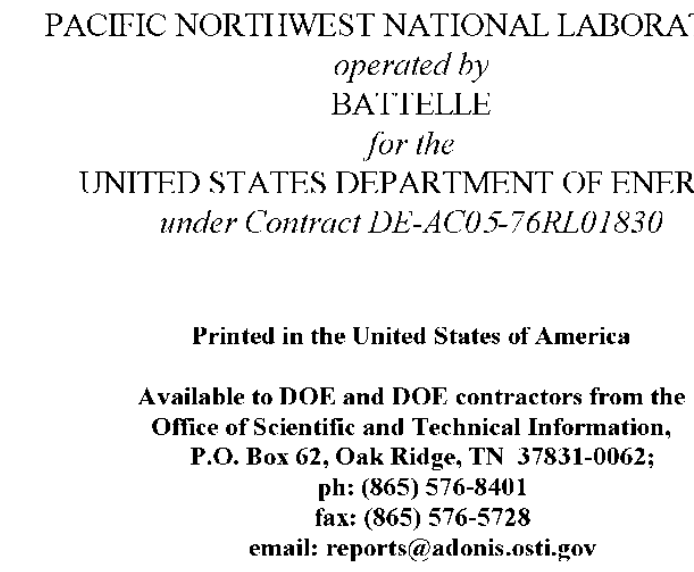

Available to the public from the National Technical Information Service, U.S. Department of Commerce, 5285 Port Royal Rd., Springfield, VA 22161 ph: (800) 553-6847 fax: (703) 605-6900 email: orders@ntis.fedworld.gov online ordering: http://www.ntis.gov/ordering.htm

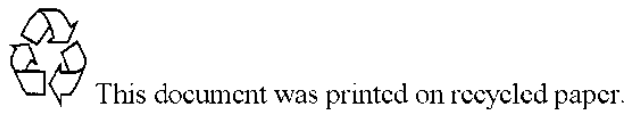

(9/2003) 


\title{
The Contribution of Environmental Siting and Permitting Requirements to the Cost of Energy for Wave Energy Devices
}

\section{Reference Model \#5}

\author{
AE Copping \\ SH Geerlofs \\ LA Hanna
}

June 2014

Prepared for

the U.S. Department of Energy

under Contract DE-AC05-76RL01830

Pacific Northwest National Laboratory

Richland, Washington 99352 



\section{Summary}

Responsible deployment of marine and hydrokinetic (MHK) devices in estuaries, coastal areas, and major rivers requires that biological resources and ecosystems be protected through siting and permitting (consenting) processes. Scoping appropriate deployment locations, collecting pre-installation (baseline) and post-installation data all add to the cost of developing MHK projects, and hence to the cost of energy. Under the direction of the U.S. Department of Energy, Pacific Northwest National Laboratory scientists have developed logic models that describe studies and processes for environmental siting and permitting. Each study and environmental permitting process has been assigned a cost derived from existing and proposed tidal, wave, and riverine MHK projects. Costs have been developed at the pilot scale and for commercial arrays for a surge wave energy converter. 



\section{Acknowledgments}

We appreciate the assistance of the engineers and scientists from Sandia National Laboratories, National Renewable Energy Laboratory, Oak Ridge National Laboratory, Advanced Research Laboratory at Penn State University and ReVision for their input and assistance in determining the designs that will affect the marine environment. We would also like to thank Brian Polagye from the University of Washington NNMREC and Glenn Cada from Oak Ridge National Laboratory for their thoughtful input on the reference model studies and costs. 



\section{Table of Contents}

$\begin{array}{lll}1.0 & \text { Introduction } & 1\end{array}$

2.0 Methods $\quad 2$

$2.1 \quad$ Siting and Scoping $\quad 3$

2.2 Pre-installation Studies, Analysis and Documentation 4

2.3 Post-installation Studies, Analysis and Documentation 5

$\begin{array}{llr}\text { 3.0 } & \text { Results } & 5\end{array}$

3.1 Pilot Project Costs $\quad 6$

3.1.1 Uncertainties in Cost Estimates for Pilot Projects $\quad 8$

3.2 Commercial Scale Costs $\quad 8$

3.2.1 Scaling Rules 9

3.2.2 Profile of Post Installation Monitoring Costs 10

3.3 Potential for Cost Savings and Refined Estimates 11

3.4 Cost Differences among MHK Technologies 12

$\begin{array}{llr}4.0 & \text { Conclusions } & 12\end{array}$

$\begin{array}{llr}5.0 & \text { References } & 13\end{array}$

$\begin{array}{lr}\text { Appendix A -Costing Tables } & 14\end{array}$ 


\section{Tables}

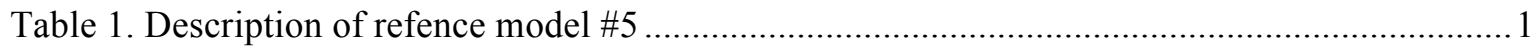

Table 2. Pre-installation and environmental concerns that are likley to require studies and analysis

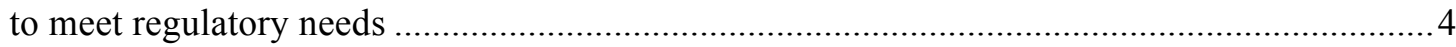

Table 3. Post-installation monitoring studies for nearshore surge WEC project development ..........5

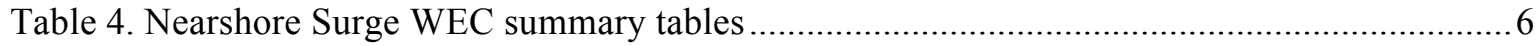

Table 5. Environmental studies that are likely to be required for each refence model stage..............6

Table 6. Examples of pilot scale study assumptions - pre-installation (baseline) studies for fish,

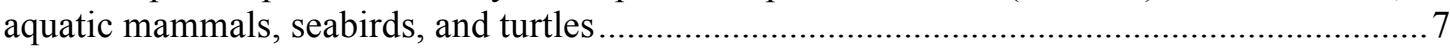

\section{Figures}

Figure 1. Conceptual design of Reference Model 5, surge WEC (courtesy of Yi-Hsiang Yu, NREL) 


\subsection{Introduction}

Responsible deployment of marine and hydrokinetic (MHK) energy devices in estuaries, coastal areas, and rivers requires that biological resources and ecosystems be protected through siting and permitting processes (Bohlert et al. 2008, Dehlsen Associates 2012). Scoping appropriate deployment locations, collecting environmental baseline data, post-installation monitoring information, and mitigating for impacts add to the cost of developing each MHK installation, and hence to the cost of energy (COE) generated. The success of the MHK industry in the U.S. depends on a favorable comparison of COE with that of other renewable energy sources (Polagye et al. 2011).

As provided for the first four reference models (tidal, riverine, wave, and ocean current), Pacific Northwest National Laboratory (PNNL) has undertaken the task of determining the preliminary costs for the major categories of environmental and site specific studies that can be expected to be needed for reference model \# 5, described in Table 1 below. PNNL's approach develops logic models that describe the expected studies for siting and permitting MHK devices, driven by the siting and regulatory processes that require those studies. Each study and environmental permitting process has been assigned a cost derived from data from existing and proposed MHK projects, scaling factors, projections for future postinstallation monitoring costs, and expert opinion.. A range of costs is presented for each type of study and regulatory requirement to reflect the significant uncertainty that results from the generic nature of the reference model site and device. Cost estimates were reviewed by agency staff, researchers, and consultants familiar with environmental permitting processes.

Table 1.Description of Refence Model \#5

\begin{tabular}{|l|l|l|l|}
\hline Reference Model & Technology & Water Body & $\begin{array}{l}\text { Marine Receptors } \\
\text { of Importance }\end{array}$ \\
\hline $\begin{array}{l}\text { \# 5 Surge Wave } \\
\text { Converter } \\
\text { (WEC) }\end{array}$ & $\begin{array}{l}\text { Surge WEC. Single large flap (25m } \\
\text { wide, 16m high, 1m thickness), } \\
\text { mounted on a floating structure } \\
\text { (43m long, 29.5m wide, and 18m } \\
\text { high), as shown in Figure 1. The } \\
\text { power generator located on } \\
\text { device. Device secured with } \\
\text { tension leg moorings to seafloor, } \\
\text { and embedment anchors. }\end{array}$ & $\begin{array}{l}\text { Located in the } \\
\text { offshore } \\
\text { environment } ~ \\
\text { meter depth) off } \\
\text { the coast of } \\
\text { Northern } \\
\text { California. }\end{array}$ & $\begin{array}{l}\text { Migratory } \\
\text { organisms } \\
\text { including marine } \\
\text { mammals and fish, } \\
\text { nearshore habitat } \\
\text { and changes in } \\
\text { sediment } \\
\text { processes. }\end{array}$ \\
\hline
\end{tabular}


Design A

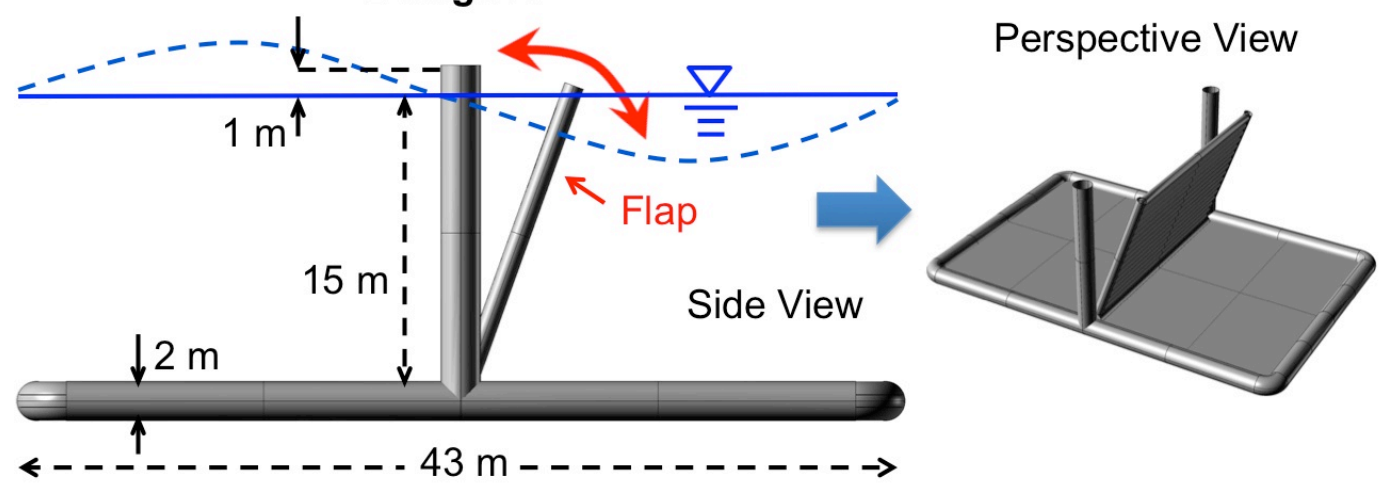

Figure 1. Conceptual design of Reference Model 5, surge WEC (courtesy of Yi-Hsiang Yu, NREL).

The goals for costing the contribution to the cost of energy (COE) from siting and permitting include:

1. Determine information needs, study requirements, and costs for each reference model for 1) scoping; 2) pre-installation; and 3) monitoring and mitigation phases, in order to assign costs to each.

2. Organize costs by major regulatory drivers-determine which regulations (and required studies) are highest cost drivers.

3. Engage regulatory agencies in the flow of studies, permitting pathways, to smooth pathway to siting and permitting.

4. Create logic-model to allow comparison of real world sites to reference model sites and determine total contribution of siting and permitting costs to COE.

This report addresses the first two goals; funding was not available to address goals \#3 and \#4.

\subsection{Methods}

Environmental studies may contribute a significant component of overall $\mathrm{COE}$ for pilot projects, and a lesser proportion for commercial scale MHK projects. In addition to the studies themselves, there is a need to account for the costs of data analysis and interpretation, and the documentation associated with the regulatory processes. Further costs are also derived from the collection of site-specific information that will assist MHK developers with choosing specific sites for development. Based on the need to account for these costs, PNNL researchers developed a set of logic models that are driven by regulatory requirements, as well as processes for collecting data that support the needs of the project developer.

The process for costing the siting and permitting contribution for $\mathrm{COE}$ was divided into three phases for reference model \#5: 1) siting and scoping; 2) pre-installation information collection; and 3) postinstallation monitoring. Costs for developing NEPA and other regulatory processes and deliverables are in addition to costs for the three phases and were developed independent of the three phases. 
While the specific sites and technologies will have a major influence on the costs for any project, there are many commonalities driven by regulatory requirements and information needs across projects. For the first three reference models (RM\#1, RM\#2, and RM\#3), PNNL researchers derived cost ranges from the best available information from existing and planned MHK projects by consulting with developers and the consultants supporting them; we also relied on the best professional judgment of researchers and natural resource management agency staff. For reference model \#5 (Surge WEC), the basis for costs of environmental studies and processes were developed through extrapolation from the previous three models. While the Surge WEC model differs considerably from RM\#3 (point absorber WEC) in its size, mooring, and operation, there are commonalities between the potential interactions of animals with the two devices. The impact of anchors and mooring lines on marine habitats in RM\#5 is somewhat analogous to the lines and anchors proposed for RM\#3 (wave). Due to the similar ocean space occupied by RM\#5, the NEPA processes and study costs can be extrapolated using PNNL staff knowledge of other nearshore MHK projects and in consultation with experts in the area (Polagye et al. 2011).

Costs for each of the RM\#5 studies and processes have been developed for pilot and commercial projects, as described. While the size of a pilot project differs from one technology and location to another, we have assumed that the RM\#5 pilot project consists of one device, totaling less than $5 \mathrm{MW}$ generation capacity, and could be deployed for up to 5 years. The scaling rules used in RM\#1-4 were applied to RM\#5 to generate a range of costs for both small and large commercial scale projects (10 and 100 devices, respectively).

Each stage of study development (scoping and siting; pre-installation assessment; post-installation monitoring) requires documentation and adherence to processes designed to meet regulatory requirements. These include conducting public meetings, filing necessary permitting paperwork, and performing periodic checks with government agencies. Each of these processes has a cost associated with it, and has been accounted for in our costing estimates. It is assumed that many of the siting and permitting processes that drive costs are included under the broad umbrella of the National Environmental Policy Act of 1969 (NEPA). Other regulatory drivers include: Endangered Species Act of 1973, Clean Water Act of 1977, Marine Mammal Protection Act of 1972 As Amended, Magnuson-Stevens Fishery Conservation and Management Act, and the Migratory Bird Treaty Act of 1918, as well as state and local regulatory requirements.

\subsection{Siting and Scoping}

Once a site has been identified that shows promise for development of tidal, wave or riverine energy, a developer will undertake feasibility investigations of the power resource potential and other information to support siting devices in specific locations. At that point, a scoping process is undertaken to identify the environmental issues of concern and to determine if there are conflicting uses for the site. Linking to ongoing ambient monitoring programs near to the proposed site will help assemble existing information. Necessary components of the scoping process include community outreach to ensure that stakeholders have a voice in determining environmental and competing use issues and to gain the trust of local leaders and the public. At the same time, project developers must work with regulatory agencies to determine what requirements they will need to meet for environmental assessment and post-installation monitoring. Each of these studies and processes has a cost associated with it that has been derived from the range of investments made by developers in the U.S. 


\subsection{Pre-installation Studies, Analysis and Documentation}

Pre-installation studies (also frequently referred to as baseline assessments) for specific wave energy projects or other similar ocean energy projects located in the offshore environment, will have site and technology-specific differences and a range of siting and permitting needs. These studies will be used to establish a baseline of environmental quality against which post-installation monitoring results can be compared to determine whether the MHK installation has had an effect. In almost all cases, the environmental areas listed in Table 2 will be required by federal and state statutes. Environmental sample collection, observation, and analysis; data management and interpretation; quality assurance and quality control; and documentation for regulatory purposes, will be needed for each study.

Table 2. Pre-installation and Environmental Concerns that are Likely to Require Studies and Analysis to meet Regulatory Needs

\begin{tabular}{|l|l|l|}
\hline Environmental Concern & $\begin{array}{l}\text { Elements of Concern/Studies } \\
\text { Needed }\end{array}$ & \multicolumn{1}{|c|}{ U.S. Regulatory Driver } \\
\hline $\begin{array}{l}\text { Species under special } \\
\text { protection }\end{array}$ & $\begin{array}{l}\text { Marine animals under threat of } \\
\text { extinction }\end{array}$ & $\begin{array}{l}\text { Endangered Species Act } \\
\text { (Endangered Species Act of 1973) }\end{array}$ \\
\hline Marine Mammals & $\begin{array}{l}\text { Concern and special societal value } \\
\text { anforded to specific groups of } \\
\text { animals }\end{array}$ & $\begin{array}{l}\text { Marine Mammal Protection Act } \\
\text { (Marine Mammal Protection Act of } \\
\text { 1972 as Amended) }\end{array}$ \\
\hline Migratory Birds & $\begin{array}{l}\text { Birds that migrate across regions } \\
\text { and continents and are considered } \\
\text { to be at risk }\end{array}$ & $\begin{array}{l}\text { Migratory Bird Treaty Act } \\
\text { (international treaty) } \\
\text { (Migratory Bird Treaty Act of 1918) }\end{array}$ \\
\hline $\begin{array}{l}\text { Important fish and shellfish } \\
\text { recreational, or cultural importance }\end{array}$ & $\begin{array}{l}\text { Magnuson-Stevens Fishery } \\
\text { Conservation, Management Act } \\
\text { (protects critical habitats and fish } \\
\text { populations) } \\
\text { (Magnuson-Stevens Fishery } \\
\text { Conservation and Management Act) }\end{array}$ \\
\hline Habitats & $\begin{array}{l}\text { Need to assess quantity and quality } \\
\text { of habitat, due to important role in } \\
\text { supporting marine species }\end{array}$ & $\begin{array}{l}\text { Magnuson Stevens Fishery } \\
\text { Conservation, Management Act, } \\
\text { other federal and state regulations } \\
\text { (Magnuson-Stevens Fishery } \\
\text { Conservation and Management Act) }\end{array}$ \\
\hline Water Quality & $\begin{array}{l}\text { Cumulative degradation of water } \\
\text { quality (DO, nutrients, human } \\
\text { transport (affecting habitats } \\
\text { shoreforms) }\end{array}$ & $\begin{array}{l}\text { Clean Water Act and state } \\
\text { equivalents } \\
\text { (Clean Water Act of 1977) }\end{array}$ \\
\hline
\end{tabular}




\subsection{Post-installation Studies, Analysis and Documentation}

Post-installation monitoring studies should be derived from the findings of pre-installation studies and other published information from relevant field and laboratory studies. For small (pilot) projects, most concerns are likely to focus close to the wave device (nearfield), focusing on the potential for animals colliding with the device or a disruption of nearfield benthic habitat. As the size of the installment grows, regulations are likely to require that studies include those focused further from the devices (farfield), including assessments of biological processes such as food web effects, effects on marine populations and communities, and altered large scale sediment processes/effects on drift cells. While site- and technologyspecific differences will drive the details of such studies, there is likely to be a certain common set of requirements (Table 3). As for pre-installation studies, sample collection, observation, and analysis; data management and interpretation; quality assurance and quality control; and documentation for regulatory purposes, have all been costed for post-installation monitoring.

Table 3. Post-installation Monitoring Studies for Nearshore Surge WEC Project Development

\begin{tabular}{|c|c|c|c|}
\hline Target of Study & Project Scale & Type of Study & Reason for the Study \\
\hline Marine Animals & Pilot and Commercial & Nearfield monitoring & \multirow{4}{*}{$\begin{array}{l}\text { Entrapment, } \\
\text { entanglement, } \\
\text { aggregation effects, } \\
\text { avoidance effects. }\end{array}$} \\
\hline $\begin{array}{l}\text { Fish, pelagic } \\
\text { invertebrates }\end{array}$ & Pilot and Commercial & Nearfield monitoring & \\
\hline $\begin{array}{l}\text { Migratory birds, diving } \\
\text { birds, seabirds }\end{array}$ & Pilot and Commercial & Nearfield monitoring & \\
\hline Sea turtles & Pilot and Commercial & Nearfield monitoring & \\
\hline Benthic invertebrates & Pilot and Commercial & Underwater survey & $\begin{array}{l}\text { Periodic survey and } \\
\text { sampling to determine } \\
\text { effects }\end{array}$ \\
\hline Acoustics of the device & Pilot and Commercial & $\begin{array}{l}\text { Noise generated by } \\
\text { WEC }\end{array}$ & $\begin{array}{l}\text { Change in acoustics } \\
\text { over time: damage, } \\
\text { harassment of marine } \\
\text { mammals, sea turtles, } \\
\text { fish, diving birds. }\end{array}$ \\
\hline Seabirds & Commercial & Ecosystem effects & \multirow{4}{*}{$\begin{array}{l}\text { Changes to pre- } \\
\text { installation population } \\
\text { status, fitness, food } \\
\text { availability and } \\
\text { preference, reproductive } \\
\text { success }\end{array}$} \\
\hline Marine mammals & Commercial & Ecosystem effects & \\
\hline $\begin{array}{l}\text { Fish, pelagic } \\
\text { invertebrates }\end{array}$ & Commercial & Ecosystem effects & \\
\hline Sea turtles & Commercial & Ecosystem effects & \\
\hline
\end{tabular}

\subsection{Results}

The overall costs for environmental studies and associated processes required for RM\#5 are summarized in Table 4. Detailed spreadsheets, references, standardized protocols, and in-depth explanation of costing is available for all parts of the environmental costing process for RM\#5 (Appendix A). It should be noted that the costs listed here are not intended to make recommendations about what 
studies should be carried out or how much they should cost, rather they reflect cost data representative of projects carried out to date and professional judgment about how the costs associated with RM\#5 may differ. Real world costs may be significantly lower or higher depending on site characteristics, regulatory concerns, and stakeholder dynamics. Costs are also expected to be reduced over time. Numbers here represent a conservative estimate, and are not intended to inform study plan negotiations between developers and regulatory agencies.

Table 4. Nearshore Surge WEC summary tables

\begin{tabular}{|c|c|c|c|c|c|c|}
\hline \multirow{2}{*}{$\begin{array}{l}\text { Information } \\
\text { Need }\end{array}$} & \multicolumn{2}{|c|}{ Pilot } & \multicolumn{2}{|c|}{ Small Scale Commercial } & \multicolumn{2}{|c|}{ Large Scale Commercial } \\
\hline & Low & High & Low & High & Low & High \\
\hline $\begin{array}{l}\text { Siting \& } \\
\text { Scoping } \\
\text { Pre- }\end{array}$ & $\$ 240,000$ & $\$ 430,000$ & 67,000 & 105,000 & 77,000 & 105,000 \\
\hline $\begin{array}{l}\text { Installation } \\
\text { Studies } \\
\text { Post- }\end{array}$ & $\$ 846,000$ & $\$ 1,583,000$ & 770,000 & $1,555,000$ & 595,000 & $1,615,000$ \\
\hline $\begin{array}{l}\text { Installation } \\
\text { NEPA \& }\end{array}$ & $\$ 320,000$ & $\$ 610,000$ & 780,000 & $2,460,000$ & 780,000 & $1,860,000$ \\
\hline Process & $\$ 725,000$ & $\$ 1,125,000$ & 70,000 & 150,000 & 70,000 & 150,000 \\
\hline Total & $\$ 2,131,000$ & $\$ 3,748,000$ & $1,907,000$ & $3,760,000$ & $1,742,000$ & $3,820,000$ \\
\hline
\end{tabular}

Costs shown here summarize total costs expected at the pilot phase and each commercial phase. Small and large scale commercial costs have been calculated under the assumption that information collected during permitting at the pilot phase would be used for permitting in the commercial phase as well, thereby achieving cost savings; these costs were calculated as incrementally adding to those of the Pilot scale.

\subsection{Pilot Project Costs}

Using data from representative pilot project study plans, the studies that are likely to be required were derived for each reference model stage (Table 5); costs were then estimated for each study. The required studies and associated costs were based on assumptions derived from project experience and expert opinion; examples of the studies and the assumptions driving these costs are shown in Table 6. Cost ranges were used to represent the breadth of studies that may be required, depending on the specific animals and habitats encountered, as well as the range of materials, personnel, and equipment available. For example, if no endangered small cetaceans (i.e., dolphins, porpoises, killer whales) were found near the project site, the marine mammal surveys costs would be reduced to focus only on the presence of large cetaceans (i.e., the great whales); if a university partner or non-profit was capable of carrying out the work, costs might be less than employing a private firm. Conversely, if new instrumentation must be developed and tested expressly for the project, costs may be higher.

Table 5. Environmental Studies that are Likely to be Required for each Refence Model Stage

\begin{tabular}{|l|l|l|l|}
\hline \multicolumn{1}{|c|}{ Siting and Scoping } & Pre-Installation Studies & Post-Installation Studies & \multicolumn{1}{|c|}{ NEPA Process } \\
\hline $\begin{array}{l}\text { Preliminary resource } \\
\text { assessment-feasibility }\end{array}$ & $\begin{array}{l}\text { Detailed resource } \\
\text { assessment }\end{array}$ & Marine mammal & $\begin{array}{l}\text { NEPA document } \\
\text { preparation }\end{array}$ \\
\hline Environmental scoping & Seabed survey, mapping & Fish & Monitoring and study \\
\hline
\end{tabular}




\begin{tabular}{|c|c|c|c|}
\hline & and bottom composition & & plans \\
\hline Community outreach & Marine mammals & Benthos & \\
\hline Regulatory outreach & Fish and invertebrates & Seabirds & \\
\hline \multirow{6}{*}{ Neguratory outiécin } & Seabirds & $\begin{array}{l}\text { Acoustic characterization } \\
\text { monitoring }\end{array}$ & \\
\hline & Turtles & & \\
\hline & Water quality & & \\
\hline & Habitat & & \\
\hline & Cultural resources & & \\
\hline & Navigation & & \\
\hline
\end{tabular}

Table 6. Examples of Pilot Scale Study Assumptions - Pre-installation (Baseline) Studies for Fish, Marine mammals, Seabirds, and Turtles

\begin{tabular}{|c|c|c|}
\hline Information Need & Specific Studies & Key Assumptions \\
\hline Marine mammals & $\begin{array}{l}\text { Baseline-distribution, species } \\
\text { identification, and behavioral } \\
\text { analysis: acoustic monitoring, } \\
\text { literature review. }\end{array}$ & $\begin{array}{l}\text { Data collection and monitoring } \\
\text { focused on migratory marine } \\
\text { mammals that use the offshore } \\
\text { environment as a migratory } \\
\text { corridor; as well as endangered } \\
\text { mammals such as the Humpback } \\
\text { whale and the Stellar sea lion. }\end{array}$ \\
\hline Fish and Invertebrates & $\begin{array}{l}\text { Baseline-distribution, species } \\
\text { identification, and behavioral } \\
\text { analysis: Split-beam } \\
\text { hydroacoustics, grab samples for } \\
\text { invertebrates, trawls, traps, and } \\
\text { other sampling methods. }\end{array}$ & $\begin{array}{l}\text { ESA listed and commercially } \\
\text { valuable species will drive the } \\
\text { studies, including highly } \\
\text { migratory species that transit } \\
\text { through this area such as ESA } \\
\text { listed salmonids and Green } \\
\text { sturgeon. Monitoring sediment } \\
\text { processes and benthic habitat in } \\
\text { the offshore and potentially } \\
\text { nearshore environment may also } \\
\text { be needed to evaluate the } \\
\text { nearfield and farfield } \\
\text { environmental effects of the } \\
\text { Surge WEC. }\end{array}$ \\
\hline Birds & $\begin{array}{l}\text { Baseline-distribution, species } \\
\text { identification, and behavioral } \\
\text { analysis: observation, literature } \\
\text { review and synthesis. }\end{array}$ & $\begin{array}{l}\text { Although this device has minimal } \\
\text { surface expression, monitoring } \\
\text { will be needed to ensure the } \\
\text { safety of coastal migratory and } \\
\text { ESA listed birds such as the } \\
\text { marbled murrelet, brown pelican } \\
\text { and arctic tern, which may be } \\
\text { present in the project area. }\end{array}$ \\
\hline Turtles & $\begin{array}{l}\text { Baseline-distribution, species } \\
\text { identification, and behavioral } \\
\text { analysis of } T \& E \text { turtles in project } \\
\text { area. }\end{array}$ & $\begin{array}{l}1 \text { year of surveys completed with } \\
\text { marine mammals surveys. While } \\
\text { it is unlikely that Leatherback } \\
\text { and Green sea turtles will migrate } \\
\text { this far north, monitoring may } \\
\text { need to be completed on a } \\
\text { seasonal basis. }\end{array}$ \\
\hline
\end{tabular}




\subsubsection{Uncertainties in Cost Estimates for Pilot Projects}

There are several uncertainties in the cost estimates for pilot projects that cannot be quantified at this time. These are:

- Monitoring Costs. Costs for post-installation monitoring are less accurate than those for preinstallation studies because pre-installation studies that have been carried out at existing pilot projects were used to inform the costs, providing a level of confidence in the information, while no such estimates exist for post-installation monitoring. Costs were estimated based on professional judgment and published studies. Yearly monitoring costs were estimated and extended to the proposed 5-year term of a FERC pilot license.

- Mitigation Costs. Mitigation costs have not been factored into the cost estimates, although mitigation for impacts to marine animals, habitats or ecosystem processes is likely to be required for most MHK projects. These costs could be added to post-installation monitoring costs, but we cannot accurately estimate the magnitude of those costs at this time.

- Uncertainty of Costs for Regulatory Requirements. There is considerable uncertainty associated with the costs for complying with NEPA and other U.S. federal and state regulatory mandates; meeting these mandates will require concentrated effort at each stage of MHK projects. The magnitude of these costs are dependent on the length of time these process require; while some applicable laws and regulations have established timelines for processing permits, these timelines are often exceeded to achieve alignment between the parties involved.

\subsection{Commercial Scale Costs}

The scaling rules used in RM\#1-4 were applied to RM\#5 to extrapolate the small and large scale commercial project costs from those of the pilot project.

Costs estimates assume that a pilot permitting process, associated studies, and short-term deployment have already taken place in the project area prior to development at the commercial scale. Cost estimates for commercial scale are for additional costs beyond the pilot study. If a developer does not follow the pilot process but goes directly to a commercial scale project (which is allowed under the FERC process), an estimate of the commercial costs for environmental siting and permitting can be derived by summing the pilot and commercial estimates.

- Pre-installation environmental studies carried out at the pilot scale focus on population and behavioral assessments to measure potential direct effects to species of concern (e.g. fish, seabirds, sea turtles, marine mammals), in order to establish a baseline for post-installation monitoring. Information gathered from these pilot studies will inform the commercial scale and studies may not have to be repeated; supplemental baseline information may be needed as the project footprint increases.

- At commercial scale, additional pre-installation studies may focus on understanding ecosystem effects from arrays. These would be additional studies beyond those carried out at the pilot scale. 
- The threshold between a small and large commercial array cannot be viewed as absolute, and must be determined on a site-specific basis. We have chosen thresholds appropriate for the reference sites we are working at, based on overall guidance of the DOE reference model project.

\subsubsection{Scaling Rules}

In addition to the assumptions that lead from pilot to commercial scale cost estimates, PNNL developed a set of "scaling rules" (Table 9) to allow for consistent comparison between changes in study costs from pilot to commercial scale; this consistency allows for relative comparison, which is useful considering the uncertainty in cost estimates.

Table 9. Rules for scaling environmental study costs from pilot to commercial scale projects.

\begin{tabular}{|c|c|c|}
\hline Scaling Rule & Explanation & Examples \\
\hline Covered in pilot & $\begin{array}{l}\text { Information need was covered under } \\
\text { the pilot project licensing process. } \\
\text { Additional funds are likely not } \\
\text { needed for studies at the } \\
\text { commercial scale. }\end{array}$ & $\begin{array}{l}\text { Desktop studies for initial determination of } \\
\text { economic and environmental feasibility. This } \\
\text { information would carry over directly into } \\
\text { commercial scale. }\end{array}$ \\
\hline Continuing costs & $\begin{array}{l}\text { Recurring costs that continue from } \\
\text { pilot into commercial scale } \\
\text { permitting processes. }\end{array}$ & $\begin{array}{l}\text { Nearfield monitoring studies may continue from } \\
\text { pilot to commercial scale, though the } \\
\text { expectation is that pilot nearfield monitoring } \\
\text { studies may answer many of the questions } \\
\text { required for commercial installation, so } \\
\text { commercial costs may be at a lower level. }\end{array}$ \\
\hline $\begin{array}{l}\text { Incremental } \\
\text { increase }\end{array}$ & $\begin{array}{l}\text { Additional costs associated with } \\
\text { larger footprint of a commercial- } \\
\text { scale project. Cost increase likely to } \\
\text { be marginal, incremental, and } \\
\text { linear. }\end{array}$ & $\begin{array}{l}\text { Resource assessment-larger project footprint } \\
\text { may require procurement and deployment of } \\
\text { additional ADCPs, ADVs, or other instruments, } \\
\text { incrementally higher equipment costs and } \\
\text { additional ship days above what would be } \\
\text { expected for a pilot-scale project. }\end{array}$ \\
\hline $\begin{array}{l}\text { Multiplicative cost } \\
\text { increase }\end{array}$ & $\begin{array}{l}\text { Significant study cost increases as } \\
\text { scale of project goes from pilot to } \\
\text { commercial, and regulators require } \\
\text { greater understanding of system or } \\
\text { basin effects. Cost increase likely to } \\
\text { be more than double the cost at the } \\
\text { pilot scale and may increase in a } \\
\text { non-linear fashion. }\end{array}$ & $\begin{array}{l}\text { Habitat surveys and mapping may be expected } \\
\text { to have a multiplicative cost increase if there is a } \\
\text { large increase in footprint from pilot to } \\
\text { commercial scale, or if a farfield habitat baseline } \\
\text { is required. }\end{array}$ \\
\hline Additional study & $\begin{array}{l}\text { Larger scale projects may require } \\
\text { studies, in addition to those required } \\
\text { for a pilot project. }\end{array}$ & $\begin{array}{l}\text { Farfield or ecosystem monitoring-Pre- } \\
\text { installation studies that characterize valued } \\
\text { species (fish, birds, marine mammals) will need } \\
\text { to be at the basin-scale. If effects of a } \\
\text { commercial project are considered to extend } \\
\text { beyond the nearfield, or if regulators require } \\
\text { "Before After Control Impact" (BACI)- style } \\
\text { monitoring in the post-installation phase, } \\
\text { completely new studies may be required. }\end{array}$ \\
\hline
\end{tabular}


Siting and scoping costs at commercial scale will increase incrementally over pilot scale costs, as the footprint of the MHK farm increases. However these costs will remain a relatively small fraction of total costs.

Pilot scale pre-installation studies may satisfy many of the regulatory needs at the commercial scale. However commercial scale projects may raise new questions about farfield or ecosystem effects, and as a result, additive studies may be necessary to assess baseline health on species of concern. Detailed hydrodynamic modeling may also be needed to inform array siting and to understand potential water quality and sediment transport effects. Finally, habitat mapping costs could increase multiplicatively when device numbers cross a threshold where farfield effects might be expected; this could lead to regulatory requirements for habitat mapping and assessment of a much larger area than that immediately adjacent to the array and associated infrastructure.

As with the pilot-scale assessment, there is considerable uncertainty in costs associated with postinstallation monitoring for commercial developments. Some of the post-installation studies carried out at the pilot scale are likely to continue. However, information collected during monitoring of pilot devices may satisfy a number of regulatory questions, particularly the risk of direct effects of devices on animals (such as blade strike). As with pre-installation studies, increases in post-installation monitoring costs may be related to additional studies to understand farfield or ecosystem effects resulting from large arrays of devices.

\subsubsection{Profile of Post Installation Monitoring Costs}

Until sufficient data exist to anticipate interactions of MHK devices with marine animals and habitats, extensive monitoring is likely to be required during the initial years of deployment at the commercial scale, resulting in front-loading of costs in the first five years. These costs are expected to be sharply reduced to an annual baseline level, with periodic increases in activity to validate the trends seen in the first five years, and to address new questions or concerns as they arise. Figure 2 shows a hypothetical cost profile over the course of a thirty-year license term for a tidal power project. 


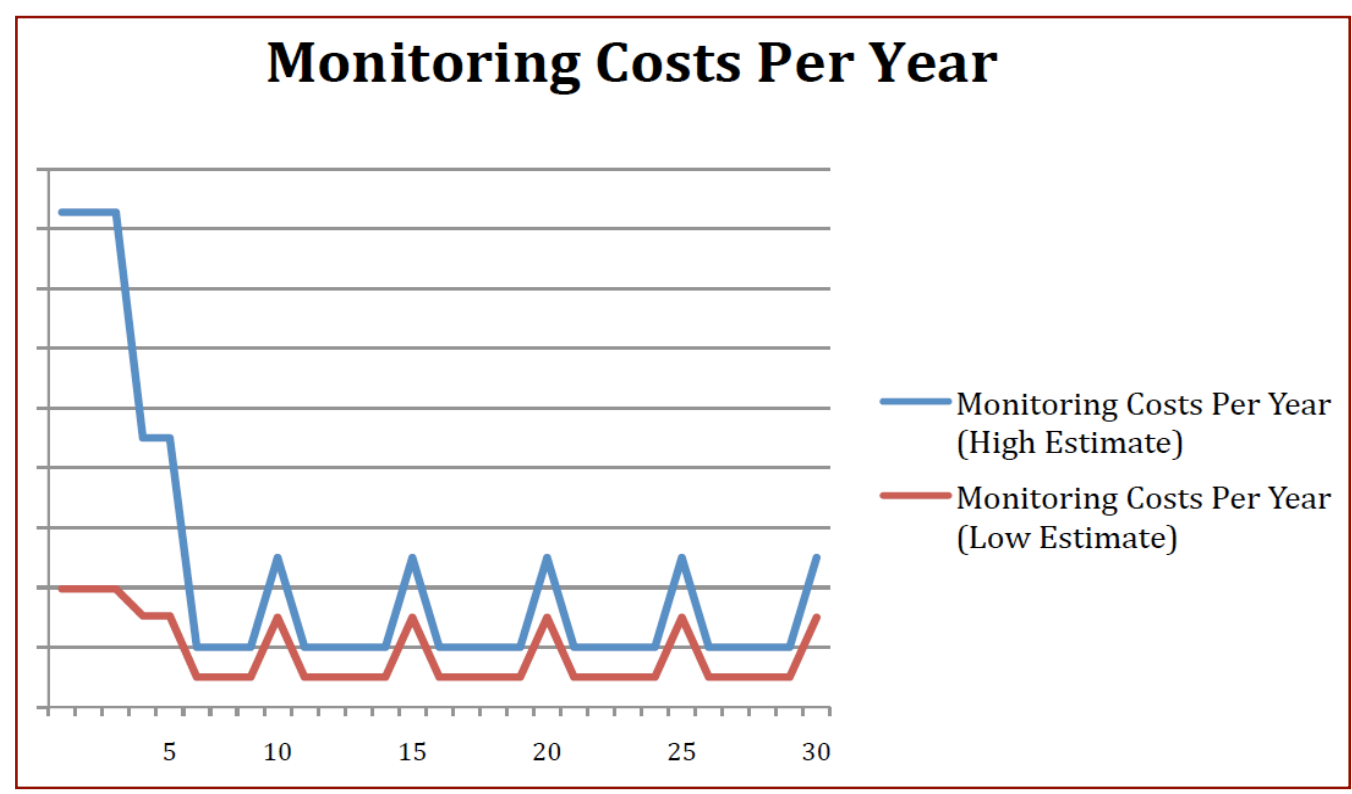

Figure 2. Hypothetical cost profile for monitoring costs over a thirty-year license term for a commercialscale tidal farm. Costing figures are not shown, as data are preliminary.

\subsection{Potential for Cost Savings and Refined Estimates}

The process PNNL used to estimate costs of environmental studies and permitting relied heavily on information from developers, researchers and consultants involved in facilitating deployment of MHK devices in the U.S. The variability of cost estimates shown for environmental studies and permitting are large, as reflected by the cost ranges (low estimate, high estimate) shown, and represent preliminary answers that require more investigation before they can be seen as reliable contributors to the COE. Each major study has been costed independently; in reality there may be considerable cost savings if baseline and monitoring studies for various organisms are combined. For example, combining shore-based observer assessments of marine mammals and sea birds will reduce the costs of monitoring; similarly, acoustic monitoring for aquatic mammals and fish can be conducted during the same cruise, using an array of acoustic imaging devices and hydrophones. Where possible, these potential efficiencies were captured in low cost estimates and described in the assumptions, but considerable variability can still be expected. With a limited number of U.S. MHK projects approaching deployment, there have been limited sources of cost data available during this study. Future iterations of this process will help hone the costs of studies and permitting, as well as determine the proportionate contributions to the COE.

The cost ranges shown for the offshore surge WEC technology reflect choices among the studies, as indicated by the logic models. As we learn more about the conditions found at proposed MHK sites, the potential effects of these devices on marine animals, habitats and ecosystem processes, and the studies required to understand and address these effects, the logic models could be revisited, with further refinement of the list of studies and associated costs for each stage of development. Similarly the scaling 
rules (Table 9) will be further refined and applied to commercial scale studies. Once sufficient study and costing data become available at the commercial scale, the scaling rules should become unnecessary and will be replaced with estimates of realistic costs.

\subsection{Cost Differences among MHK Technologies}

Factors such as waterbody characteristics, MHK technologies, and the marine animals and habitats indigenous to the site will be reflected in differences among permitting and siting costs for MHK projects in the U.S. As more MHK sites are chosen for development, additional permitting requirements and siting complexities may arise causing even greater divergence in permitting and siting costs.

Offshore surge WEC (RM \#5) is located in the offshore marine environment in approximately 50 meters of water. Extensive pre- and post- installation monitoring will be needed to better understand the interaction between this device and migratory marine mammals, fish and reptiles; endangered species like the Humpback whale, Stellar sea lion, Chinook salmon and Green sturgeon will inhabit this environment during migration and for feeding. The sediment processes within the offshore and nearshore environment may also be at risk, and may require modeling and monitoring efforts to examine how the reduction of wave energy will affect sediment processes, subtidal habitats and shore forms. RM\#5 may also require sea bird studies particularly for marbled murrelet, brown pelican and the arctic tern.

\subsection{Conclusions}

Estimating costs of environmental studies and permitting provides input to the COE, and also serves other purposes. These estimates may assist developers in determining upfront and ongoing costs of developing projects, as well as planning linked studies from pre-installation assessment to post installation monitoring, and developing mitigation strategies. Probably most important, the process of determining appropriate studies to meet regulatory needs can assist the standardization of a pathway for installing MHK projects in the water and expanding towards commercial production of power. 


\subsection{References}

Boehlert, G., G. McMurray, and C. Tortorici. 2008. Ecological effects of wave energy development in the Pacific Northwest: a scientific workshop, October 11-12, 2007. U.S. Department of Commerce.

Clean Water Act of 1977. 1977. Public Law 95-217, as amended, 33 USC 1251 et seq.

Dehlsen Associates. 2012. Siting Study for a Hydrokinetic Energy Project Located Offshore Southeastern Florida: Protocols for Survey Methodology for Offshore Marine Hydrokinetic Energy Projects. The U.S. Department of Energy, Washington D.C.

Eichbaum, W.M., M.P. Crosby, M.T. Agardy and S.A. Laskin. 1996. The Role of Marine and Coastal Protected Areas in the Conservation and Sustainable Use of Biological Diversity.

Oceanography 9(1):60-70, http://dx.doi.org/10.5670/oceanog.1996.28

Endangered Species Act of 1973. 1973. Public Law 93-205, as amended, 16 USC 1531 et seq.

Magnuson-Stevens Fishery Conservation and Management Act. 16 U.S.C. 1801-1882, April 13, 1976, as amended 1978-1980, 1982-1984, 1986-1990, 1992-1994, and 1996.

Marine Mammal Protection Act of 1972 as Amended. 2007. 16 USC 1361 et seq.

Migratory Bird Treaty Act of 1918. 1918. 40 Stat. 755, as amended, 16 USC 710.

National Environmental Policy Act of 1969. 1969. Public Law 91-190, as amended, 42 USC 4321 et seq.

Polagye, B., A. Copping, K. Kirkendall, G. Boehlert, S. Walker, M. Weinstein, B. Van Cleve. 2011. Environmental Effects of Tidal Energy Development: A Scientific Workshop. University of Washington, Seattle, Washington, March 22-24, 2010. NMFS F/SPO-116, NOAA, Seattle WA. 
Appendix A-Costing Tables 
Summary Table of Reference Model \# 5 (Nearshore Surge WEC)

\begin{tabular}{|c|c|c|}
\hline \multirow[b]{2}{*}{ Information Need } & \multicolumn{2}{|c|}{ Pilot } \\
\hline & Low & \\
\hline Siting \& Scoping & $\$ 240,000$ & $\$ 430,000$ \\
\hline Pre-Installation Studies & $\$ 846,000$ & $\$ 1,583,000$ \\
\hline Post-Installation & $\$ 320,000$ & $\$ 610,000$ \\
\hline NEPA \& Process & $\$ 725,000$ & $\$ 1,125,000$ \\
\hline Total & $\$ 2,131,000$ & $\$ 3,748,000$ \\
\hline
\end{tabular}

\section{Pilot Costs}

Pilot - Siting and Scoping

\begin{tabular}{|c|c|c|c|c|}
\hline Information Need & Specific Studies & $\begin{array}{l}\text { Low } \\
\text { Cost }\end{array}$ & High Cost & Key Assumptions \\
\hline $\begin{array}{l}\text { Preliminary } \\
\text { Resource } \\
\text { Assessment- } \\
\text { Feasibility }\end{array}$ & $\begin{array}{l}\text { Assessment of } \\
\text { waves heights, } \\
\text { lengths, periods } \\
\text { over seasons }\end{array}$ & 90,000 & 90,000 & $\begin{array}{l}\text { NCEP-NOPP Wavewach } \\
\text { III } 30 \text {-yr hindcast } \\
\text { dataset would be ideal } \\
\text { for the analysis, but } \\
\text { there is no wave watch } \\
\text { data within } 5 \text { miles } \\
\text { from shore. Will require } \\
\text { characterization of } \\
\text { inshore wave climate 1) } \\
\text { obtain wave climate } \\
\text { parameters; } 2 \text { ) } \\
\text { construct wave spectra } \\
\text { (and calibrated spectral } \\
\text { shape coefficients if } \\
\text { data available); } 3 \text { ) } \\
\text { calculated wave power } \\
\text { density and estimate } \\
\text { wave energy flux; 4) } \\
\text { report }\end{array}$ \\
\hline $\begin{array}{l}\text { Environmental } \\
\text { Scoping }\end{array}$ & $\begin{array}{l}\text { Desktop } \\
\text { study-review } \\
\text { existing } \\
\text { information on } \\
\text { key species and } \\
\text { habitats as well } \\
\text { as competing } \\
\text { uses. }\end{array}$ & 50,000 & 100,000 & $\begin{array}{l}\text { Used for preliminary } \\
\text { NEPA scoping and to } \\
\text { identify key information } \\
\text { needs for pre- } \\
\text { installation studies. }\end{array}$ \\
\hline $\begin{array}{l}\text { Community } \\
\text { Outreach }\end{array}$ & $\begin{array}{l}\text { Targeted } \\
\text { information } \\
\text { delivery, } \\
\text { community } \\
\text { meetings, } \\
\text { workshops and } \\
\text { visual impact } \\
\text { study }\end{array}$ & 50,000 & 80,000 & $\begin{array}{l}\text { Development of } \\
\text { materials and } \\
\text { information to address } \\
\text { anticipated stakeholder } \\
\text { concerns and frame the } \\
\text { value of the project to } \\
\text { the community, } \\
\text { attending or hosting 3- } \\
4 \text { meetings with } \\
\text { existing organizations, } \\
\text { potential focus groups. }\end{array}$ \\
\hline
\end{tabular}




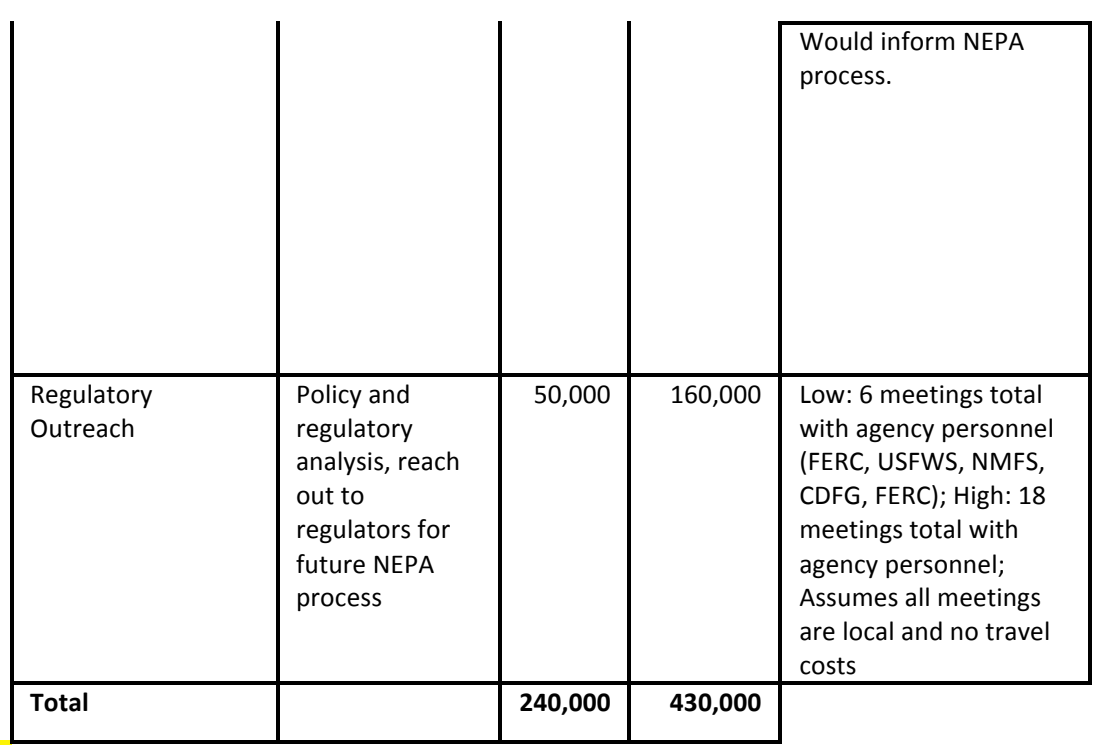

Pilot - Pre-Installation Studies

\begin{tabular}{|c|c|c|c|c|}
\hline Information Need & Specific Studies & $\begin{array}{l}\text { Low } \\
\text { Cost }\end{array}$ & High Cost & Key Assumptions \\
\hline $\begin{array}{l}\text { Seabed Survey and } \\
\text { Mapping }\end{array}$ & $\begin{array}{l}\text { Side-scan } \\
\text { survey of site } \\
\text { area, ROV or } \\
\text { diver survey at } \\
\text { site, compile } \\
\text { data and create }\end{array}$ & 110,000 & 110,000 & $\begin{array}{l}\text { Cost for field work + } \\
\text { equipment; includes } 2 \\
\text { days to survey project } \\
\text { site and cable route } \\
(\$ 47 \mathrm{k}) \text {. Also assumes } \\
\text { cost for diver hazard } \\
\text { pay. Mapping assumes } \\
\text { lab work, data enter, } \\
\text { analysis, and report } \\
\text { writing }(\$ 62 \mathrm{~K})\end{array}$ \\
\hline Marine Mammals & $\begin{array}{l}\text { Baseline- } \\
\text { distribution, } \\
\text { species } \\
\text { identification, } \\
\text { and behavioral } \\
\text { analysis: } \\
\text { acoustic } \\
\text { monitoring, } \\
\text { shore-based } \\
\text { observation, } \\
\text { and literature } \\
\text { review. }\end{array}$ & 50,000 & 100,000 & $\begin{array}{l}1 \text { year study. Shore } \\
\text { based observers for } \\
\text { gray whale surveys in } \\
\text { spring and winter; } \\
\text { resident gray and } \\
\text { humpbacks in summer } \\
\text { and fall; acoustic } \\
\text { monitoring with } \\
\text { autonomous recorders } \\
\text { for other species (i.e., } \\
\text { dolphins and } \\
\text { porpoises)- includes } \\
\text { boat time to set and } \\
\text { retrieve recorders. High } \\
\text { end includes small } \\
\text { plane surveys. }\end{array}$ \\
\hline $\begin{array}{l}\text { Fish and } \\
\text { Invertebrates }\end{array}$ & $\begin{array}{l}\text { Baseline- } \\
\text { distribution, } \\
\text { species } \\
\text { identification, } \\
\text { and behavioral } \\
\text { analysis: } \\
\text { Telemetry and } \\
\text { tagging for } \\
\text { sturgeon, grab } \\
\text { samples for } \\
\text { invertebrates, } \\
\text { trapping for } \\
\text { crabs, trawling } \\
\text { for fish. } \\
\end{array}$ & 469,000 & 765,000 & $\begin{array}{l}2 \text { years of pre- } \\
\text { installation monitoring } \\
\text { as required by } \\
\text { agencies; } 1 \text { ) Telemetry } \\
\text { receivers to detect } \\
\text { tagged ESA-listed } \\
\text { sturgeon; } 2 \text { ) Grab } \\
\text { sampling to assess } \\
\text { benthic inverts; } 3 \text { ) } \\
\text { Trapping to assess } \\
\text { Dungeness crab; 4) } \\
\text { Trawling to assess } \\
\text { demersal fish and } \\
\text { benthic invertebrates. }\end{array}$ \\
\hline
\end{tabular}




\begin{tabular}{|c|c|c|c|c|}
\hline Seabirds/Shorebirds & $\begin{array}{l}\text { Baseline- } \\
\text { distribution, } \\
\text { species } \\
\text { identification, } \\
\text { and behavioral } \\
\text { analysis: shore } \\
\text { based surveys } \\
\text { and beach } \\
\text { transects }\end{array}$ & 20,000 & 40,000 & $\begin{array}{l}1 \text { year of shore based } \\
\text { surveys. }\end{array}$ \\
\hline Turtles & $\begin{array}{l}\text { Baseline-- } \\
\text { distribution, } \\
\text { species } \\
\text { identification, } \\
\text { and behavioral } \\
\text { analysis of T\&E } \\
\text { turtles in } \\
\text { project area. } \\
\text { Shore based } \\
\text { surveys. }\end{array}$ & 12,000 & 38,000 & $\begin{array}{l}1 \text { year of surveys. Low: } \\
\text { shore based surveys; } \\
\text { High- surveys done } \\
\text { from small aircraft }\end{array}$ \\
\hline $\begin{array}{l}\text { Sediment } \\
\text { Transport/Water } \\
\text { Quality }\end{array}$ & $\begin{array}{l}\text { Baseline-CTD } \\
\text { point casts; } \\
\text { sediment } \\
\text { transport } \\
\text { modeling to } \\
\text { indicate } \\
\text { changes in } \\
\text { sediment } \\
\text { transport. }\end{array}$ & 100000 & 220000 & $\begin{array}{l}\text { Nearshore WEC devices } \\
\text { may raise concerns for } \\
\text { sediment transport } \\
\text { processes and effects } \\
\text { to shoreforms. } \\
\text { Sediment transport } \\
\text { modeling may be } \\
\text { required, and validation } \\
\text { sampling. CTD casts and } \\
\text { sediment traps may } \\
\text { also be required. }\end{array}$ \\
\hline Habitat & $\begin{array}{l}\text { Benthic surveys } \\
\text { covered in } \\
\text { seabed analysis } \\
\text { above. } \\
\text { Nearshore } \\
\text { surveys } \\
\text { conducted by } \\
\text { plant ecologists }\end{array}$ & 20,000 & 20,000 & $\begin{array}{l}\text { Botanical surveys, dune } \\
\text { surveys. } 1 \text { week }(5 \mathrm{~d}) \text {, } \\
\text { assumes no new } \\
\text { transmission line. Does } \\
\text { not include wetland } \\
\text { delineation. }\end{array}$ \\
\hline Cultural Resources & $\begin{array}{l}\text { Three phases: } \\
\text { Inventory, } \\
\text { testing, data } \\
\text { recovery. And } \\
\text { assessment of } \\
\text { traditional } \\
\text { cultural } \\
\text { properties. }\end{array}$ & 15,000 & 195,000 & $\begin{array}{l}\text { Low estimate is for } \\
\text { historic properties } \\
\text { inventory only. High } \\
\text { estimate reflects } \\
\text { testing and data } \\
\text { recovery that would } \\
\text { only be necessary if } \\
\text { sites are found that } \\
\text { cannot be avoided. } \\
\text { Estimates are for } \\
\text { shoreline sites only; } \\
\text { seabed survey would } \\
\text { identify submerged } \\
\text { cultural resources that } \\
\text { could be avoided } \\
\text { through siting. }\end{array}$ \\
\hline Navigation & $\begin{array}{l}\text { Establish vessel } \\
\text { traffic baseline, } \\
\text { risk assessment. }\end{array}$ & 10,000 & 15,000 & $\begin{array}{l}\text { Surveys or interviews of } \\
\text { commercial mariners, } \\
\text { fishers and recreational } \\
\text { boaters. }\end{array}$ \\
\hline
\end{tabular}




\begin{tabular}{|l|l|l|l|l|} 
& $\begin{array}{l}\text { Recreation } \\
\text { overview and } \\
\text { initial impact } \\
\text { assessment }\end{array}$ & $\mathbf{4 0 , 0 0 0}$ & $\mathbf{8 0 , 0 0 0}$ & $\begin{array}{l}\text { Focus on boat and } \\
\text { shore based fishing, sail } \\
\text { and powerboat } \\
\text { navigation and access, } \\
\text { surfing, shore-based } \\
\text { use in viewshed. 3-9 } \\
\text { month study, } \\
\text { interviews, site visit, } \\
\text { meetings with } \\
\text { developer and staff, } \\
\text { summary of existing } \\
\text { data, summary report. }\end{array}$ \\
\hline Total & & $\mathbf{8 4 6 , 0 0 0}$ & $\mathbf{1 , 5 8 3 , 0 0 0}$ &
\end{tabular}

\section{Pilot - Post Installation Monitoring}

\begin{tabular}{|c|c|c|c|c|}
\hline Information Need & Specific Studies & $\begin{array}{l}\text { Low } \\
\text { Cost }\end{array}$ & High Cost & Key Assumptions \\
\hline $\begin{array}{l}\text { Marine Mammals } \\
\text { and Turtles }\end{array}$ & $\begin{array}{l}\text { Monitoring- } \\
\text { Strike, } \\
\text { aggregation } \\
\text { effects, } \\
\text { avoidance } \\
\text { effects. } \\
\text { Continuation of } \\
\text { baseline } \\
\text { assessment. }\end{array}$ & 50,000 & 100,000 & $\begin{array}{l}\text { (costs are for one year } \\
\text { of monitoring- } \\
\text { multiple years may be } \\
\text { required). Shore based } \\
\text { observers for gray } \\
\text { whale surveys in spring } \\
\text { and winter; resident } \\
\text { gray and humpbacks in } \\
\text { summer and fall; } \\
\text { acoustic monitoring } \\
\text { with autonomous } \\
\text { recorders for other } \\
\text { species (i.e., dolphins } \\
\text { and porpoises)- } \\
\text { includes boat time to } \\
\text { set and retrieve } \\
\text { recorders. High end } \\
\text { includes small plane } \\
\text { surveys. Fish cameras } \\
\text { might see marine } \\
\text { mammals. }\end{array}$ \\
\hline Fish & $\begin{array}{l}\text { Monitoring- } \\
\text { Strike, } \\
\text { aggregation } \\
\text { effects, } \\
\text { avoidance } \\
\text { effects. }\end{array}$ & 150,000 & 325,000 & $\begin{array}{l}\text { costs are for one year } \\
\text { of monitoring- } \\
\text { multiple years may be } \\
\text { required) Equipment } \\
\text { costs includes lights } \\
\text { and camera package, } \\
\text { tagging, active } \\
\text { acoustics (100-250k). } \\
\text { Operating costs are } \\
\text { recurring yearly (50- } \\
75 k \text { ). Tremendous } \\
\text { uncertainty here-costs } \\
\text { could be much higher } \\
\text { depending on agency } \\
\text { needs. }\end{array}$ \\
\hline Seabirds/Shorebirds & $\begin{array}{l}\text { Monitoring- } \\
\text { Strike, } \\
\text { aggregation } \\
\text { effects, } \\
\text { avoidance } \\
\text { effects. } \\
\text { Continuation of } \\
\text { baseline } \\
\text { assessment. }\end{array}$ & 20,000 & 40,000 & $\begin{array}{l}\text { (costs are for one year } \\
\text { of monitoring- } \\
\text { multiple years may be } \\
\text { required) Shore based } \\
\text { observation and survey. }\end{array}$ \\
\hline
\end{tabular}




\begin{tabular}{|c|c|c|c|c|}
\hline Benthos & $\begin{array}{l}\text { Periodic survey } \\
\text { and sampling to } \\
\text { determine } \\
\text { effects on } \\
\text { benthic } \\
\text { organisms and } \\
\text { community } \\
\end{array}$ & 60,000 & 100,000 & $\begin{array}{l}\text { (costs are for one year } \\
\text { of monitoring- } \\
\text { multiple years may be } \\
\text { required) Diver and } \\
\text { boat surveys, } 3-4 \\
\text { survey days per year. }\end{array}$ \\
\hline $\begin{array}{l}\text { Acoustic } \\
\text { Characterization } \\
\text { Monitoring }\end{array}$ & $\begin{array}{l}\text { Noise coming } \\
\text { off WECs }\end{array}$ & 40,000 & 45,000 & $\begin{array}{l}\text { (costs are for one year } \\
\text { of monitoring- } \\
\text { multiple years may be } \\
\text { required) Initial } \\
\text { investment of } 40 \mathrm{k} \text {, then } \\
5 \mathrm{k} \text { recurring per year. }\end{array}$ \\
\hline Total & & 320,000 & 610,000 & \\
\hline
\end{tabular}

\section{Pilot - NEPA and Process}

\begin{tabular}{|l|l|l|c|l|}
\hline Information Need & Specific Studies & $\begin{array}{l}\text { Low } \\
\text { Cost }\end{array}$ & High Cost & Key Assumptions \\
\hline $\begin{array}{l}\text { NEPA Document } \\
\text { Preparation }\end{array}$ & $\begin{array}{l}\text { Consulting firm } \\
\text { contract }\end{array}$ & 600,000 & $1,000,000$ & $\begin{array}{l}\text { Agency consultation, } \\
\text { Biological Assessment, } \\
\text { MMPA permits, 404 } \\
\text { water quality permit, } \\
\text { CZMA, draft and final } \\
\text { EIS, draft and final } \\
\text { license agreement. }\end{array}$ \\
\hline $\begin{array}{l}\text { Monitoring and } \\
\text { Study Plans }\end{array}$ & $\begin{array}{l}\text { Consultants or } \\
\text { research } \\
\text { partners }\end{array}$ & 125,000 & 125,000 & $\begin{array}{l}\text { Separate study plans } \\
\text { prepared for 1) marine } \\
\text { mammals \& sea turtles, } \\
\text { 2) fish, invertebrates, \& } \\
\text { water quality, 3) } \\
\text { seabirds. Assumes } \\
\text { several iterations for } \\
\text { each study plan needed } \\
\text { to satisfy agency } \\
\text { concerns. }\end{array}$ \\
\hline Total & & $\mathbf{7 2 5 , 0 0 0}$ & $\mathbf{1 , 1 2 5 , 0 0 0}$ & \\
& & & & \\
& & & & \\
\hline
\end{tabular}




\section{Commercial Costs}

\begin{tabular}{|c|c|c|c|c|c|c|c|}
\hline \multicolumn{8}{|l|}{$\begin{array}{l}\text { Commercial - Siting } \\
\text { and Scoping }\end{array}$} \\
\hline & $\begin{array}{c}\text { Information } \\
\text { Need }\end{array}$ & $\begin{array}{l}\text { Specific } \\
\text { Studies }\end{array}$ & 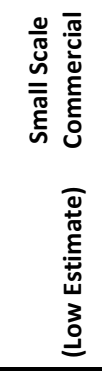 & 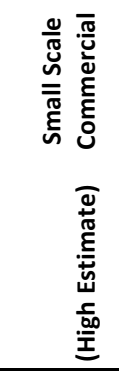 & 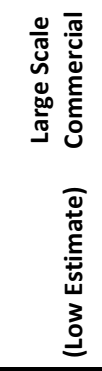 & 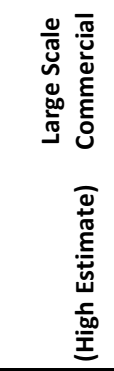 & $\begin{array}{l}\text { Scaling Rules-Scaling up } \\
\text { from pilot }\end{array}$ \\
\hline & $\begin{array}{l}\text { Preliminary } \\
\text { Resource } \\
\text { Assessment } \\
\text {-Feasibility }\end{array}$ & $\begin{array}{l}\text { Desktop } \\
\text { feasibility- } \\
\text { max flow } \\
\text { rate, cross } \\
\text { sectional } \\
\text { area, } \\
\text { length of } \\
\text { channel: } \\
\text { Theoretical } \\
\text { resource } \\
\end{array}$ & 0 & 0 & 0 & 0 & $\begin{array}{l}\text { Covered in Pilot-Study at } \\
\text { pilot scale directly } \\
\text { applicable to small- and } \\
\text { large-scale commercial. }\end{array}$ \\
\hline & $\begin{array}{l}\text { Environment } \\
\text { al Scoping }\end{array}$ & $\begin{array}{l}\text { Desktop } \\
\text { study- } \\
\text { review } \\
\text { existing } \\
\text { information }\end{array}$ & 10,000 & 10,000 & 10,000 & 10,000 & $\begin{array}{l}\text { Incremental Increase-Pilot } \\
\text { study } \$ 10 \mathrm{k} \text { provides most of } \\
\text { the necessary information, } \\
\text { may need to be updated for } \\
\text { the commercial process. }\end{array}$ \\
\hline & $\begin{array}{l}\text { Community } \\
\text { Outreach } \\
\text { (Note: } \\
\text { Community } \\
\text { outreach } \\
\text { continues } \\
\text { through all } \\
\text { project } \\
\text { phases) }\end{array}$ & $\begin{array}{l}\text { Targeted } \\
\text { information } \\
\text { delivery, } \\
\text { community } \\
\text { meetings, } \\
\text { workshops }\end{array}$ & 50,000 & 80,000 & 60,000 & 80,000 & $\begin{array}{c}\text { Continuing Cost, } \\
\text { Incremental Increase-Pilot } \\
\text { costs: } \$ 50 \mathrm{k}-\$ 60 \text { : Outreach } \\
\text { budget may increase for } \\
\text { commercial scale, based on } \\
\text { the difference in length of } \\
\text { permitting process- } \\
\text { anticipated at } 1.5 \text { years for a } \\
\text { pilot, } 5.5 \text { years for a } \\
\text { commercial project } \\
\text { following FERC's ILP process } \\
\text { waters. Longer process will } \\
\text { required more in-depth } \\
\text { outreach, more public } \\
\text { meetings, greater need for } \\
\text { facilitated stakeholder } \\
\text { interactions. Potential for } \\
\text { broader stakeholder group. }\end{array}$ \\
\hline & $\begin{array}{l}\text { Regulatory } \\
\text { Outreach }\end{array}$ & $\begin{array}{l}\text { Policy and } \\
\text { regulatory } \\
\text { analysis, } \\
\text { reach out } \\
\text { to } \\
\text { regulators } \\
\text { for future } \\
\text { NEPA } \\
\text { process }\end{array}$ & 7,000 & 15,000 & 7,000 & 15,000 & $\begin{array}{c}\text { Continuing Cost, } \\
\text { Incremental Increase-Pilot } \\
\text { costs: \$5k-10k: For a small- } \\
\text { scale and large-scale } \\
\text { commercial project, } \\
\text { additional outreach would } \\
\text { be needed beyond the pilot } \\
\text { and costs would likely } \\
\text { increase, based on larger } \\
\text { potential footprint and } \\
\text { expected level of regulatory } \\
\text { concern. } \\
\end{array}$ \\
\hline & Total & & 67,000 & 105,000 & 77,000 & 105,000 & \\
\hline
\end{tabular}




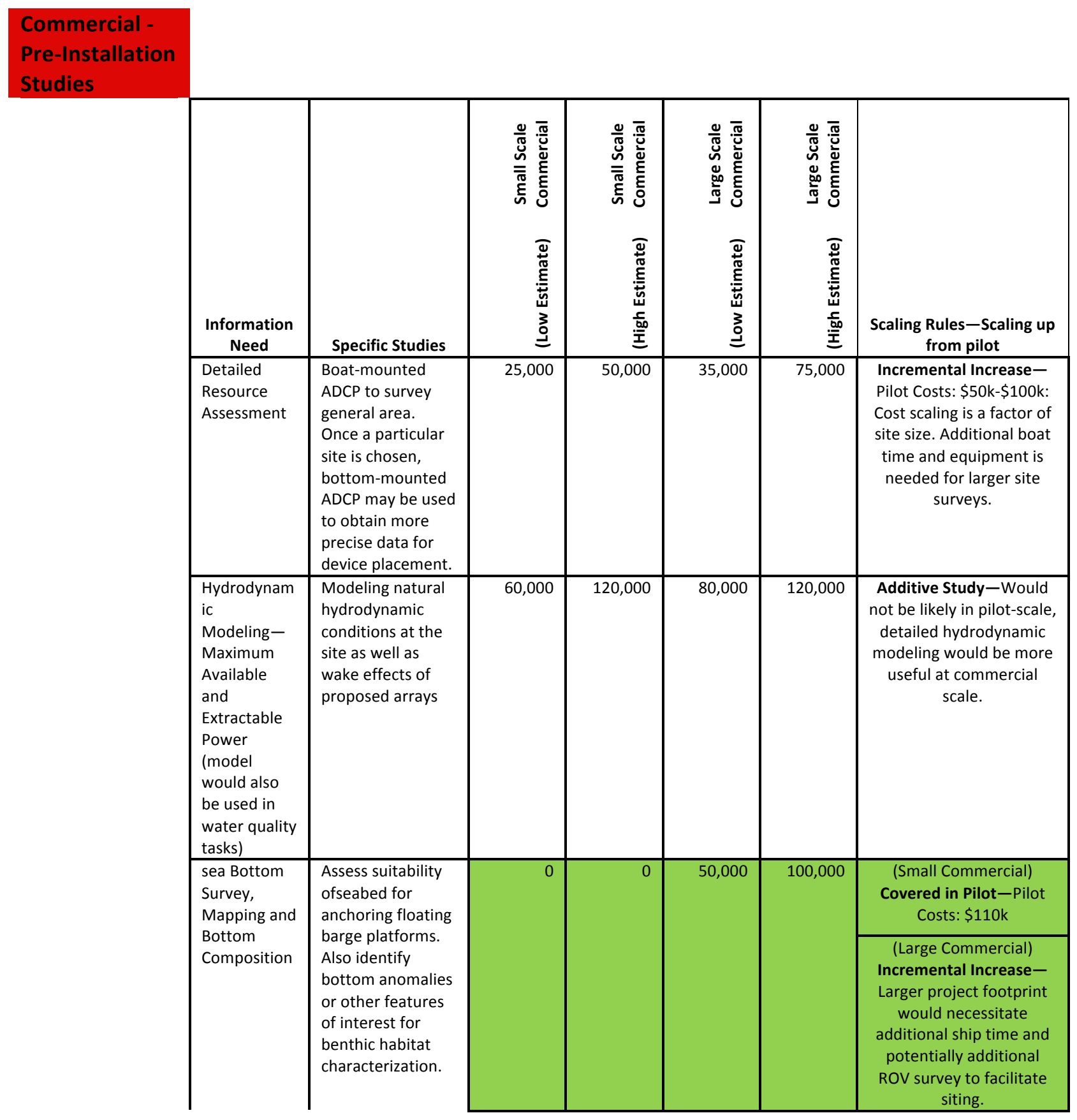




\begin{tabular}{|c|c|c|c|c|c|c|}
\hline $\begin{array}{l}\text { Marine } \\
\text { Mammals } \\
\text { and sea } \\
\text { turtles }\end{array}$ & $\begin{array}{l}\text { Baseline } \\
\text { Condition- } \\
\text { Population } \\
\text { analysis, food } \\
\text { availability and } \\
\text { preference, } \\
\text { reproduction- } \\
\text { compare to } \\
\text { existing data } \\
\text { (assuming } \\
\text { availability) }\end{array}$ & 150,000 & 240,000 & 40,000 & 100,000 & $\begin{array}{l}\text { Additive Study-Pilot } \\
\text { Costs: } \$ 485 \mathrm{k}-\$ 620 \mathrm{k} \text {. } \\
\text { Baseline at pilot scale } \\
\text { collected population, } \\
\text { distribution, and behavior } \\
\text { to assess direct effects. } \\
\text { Pilot scale information } \\
\text { will be applicable to } \\
\text { commercial scale, but } \\
\text { additional studies needed } \\
\text { to assess system-wide } \\
\text { effects on habitat and } \\
\text { food supply due to } \\
\text { operation of arrays. } \\
\text { Could be used in } \\
\text { potential BACl-like } \\
\text { monitoring studies, if } \\
\text { required. }\end{array}$ \\
\hline $\begin{array}{l}\text { Fish and } \\
\text { Invertebrate } \\
\mathrm{s}\end{array}$ & $\begin{array}{l}\text { Baseline Health- } \\
\text { Population } \\
\text { analysis, food } \\
\text { availability and } \\
\text { preference, } \\
\text { reproduction- } \\
\text { compare to } \\
\text { existing data } \\
\text { (assuming } \\
\text { availability) }\end{array}$ & 250,000 & 370,000 & 30,000 & 100,000 & $\begin{array}{l}\text { Additive Study-Pilot } \\
\text { Costs: } \$ 469 \mathrm{k}-\$ 765 \mathrm{k} \text {. } \\
\text { Baseline at pilot scale } \\
\text { collected population, } \\
\text { distribution, and behavior } \\
\text { to assess direct effects. } \\
\text { Pilot scale information } \\
\text { will be applicable to } \\
\text { commercial scale, but } \\
\text { additional studies needed } \\
\text { to assess system-wide } \\
\text { effects on habitat and } \\
\text { food supply due to } \\
\text { operation of arrays. } \\
\text { Could be used in } \\
\text { potential BACl-like } \\
\text { monitoring studies, if } \\
\text { required. }\end{array}$ \\
\hline Seabirds & $\begin{array}{l}\text { Baseline } \\
\text { Condition- } \\
\text { Population } \\
\text { analysis, food } \\
\text { availability and } \\
\text { preference, } \\
\text { reproduction- } \\
\text { compare to } \\
\text { existing data } \\
\text { (assuming } \\
\text { availability) }\end{array}$ & 30,000 & 100,000 & 30,000 & 100,000 & $\begin{array}{l}\text { Additive Study-Pilot } \\
\text { Costs: } \$ 37 \mathrm{k}-\$ 150 \mathrm{k} \text {. } \\
\text { Baseline at pilot scale } \\
\text { collected population, } \\
\text { distribution, and behavior } \\
\text { to assess direct effects. } \\
\text { Pilot scale information } \\
\text { will be applicable to } \\
\text { commercial scale, but } \\
\text { additional studies needed } \\
\text { to assess system-wide } \\
\text { effects on habitat and } \\
\text { food supply due to } \\
\text { operation of arrays. } \\
\text { Could be used in } \\
\text { potential BACl-like } \\
\text { monitoring studies, if } \\
\text { required. }\end{array}$ \\
\hline $\begin{array}{l}\text { Water } \\
\text { Quality and } \\
\text { Sediment } \\
\text { Transport } \\
\text { Modeling }\end{array}$ & $\begin{array}{l}\text { Baseline-CTD } \\
\text { point casts; } \\
\text { sediment } \\
\text { transport } \\
\text { modeling to } \\
\text { indicate changes } \\
\text { in sediment } \\
\text { transport. }\end{array}$ & 100,000 & 220,000 & 100,000 & 220,000 & $\begin{array}{l}\text { Additive Study-WEC } \\
\text { arrays may raise concerns } \\
\text { for sediment transport } \\
\text { processes and effects to } \\
\text { shoreforms. Sediment } \\
\text { transport modeling may } \\
\text { be required at both small- } \\
\text { and large-scale } \\
\text { commercial, and } \\
\text { validation sampling. CTD } \\
\text { casts and sediment traps }\end{array}$ \\
\hline
\end{tabular}




\begin{tabular}{|c|c|c|c|c|c|c|}
\hline & & & & & & may also be required. \\
\hline Habitat & $\begin{array}{l}\text { From seabed } \\
\text { survey conducted } \\
\text { in pilot, } \\
\text { development of } \\
\text { habitat maps and } \\
\text { nearshore survey }\end{array}$ & 30,000 & 50,000 & 80,000 & 375,000 & $\begin{array}{l}\text { (Small commercial) } \\
\text { Incremental Increase- } \\
\text { Small increase in costs to } \\
\text { factor in studies habitat } \\
\text { mapping for a slightly } \\
\text { larger project footprint. } \\
\text { At the small commercial } \\
\text { scale, you still do not } \\
\text { expect far field effects on } \\
\text { habitat from turbine } \\
\text { operation. } \\
\text { (large commercial) } \\
\text { Multiplicative Increase- } \\
\text { when WEC numbers cross } \\
\text { a threshold where you } \\
\text { would begin to expect far } \\
\text { field effects, habitat } \\
\text { assessment and mapping } \\
\text { would likely be required } \\
\text { for a larger area. May } \\
\text { require additional surveys } \\
\text { and data collection, such } \\
\text { as LIDAR. }\end{array}$ \\
\hline $\begin{array}{l}\text { Cultural } \\
\text { Resources }\end{array}$ & $\begin{array}{l}\text { Three phases: } \\
\text { Inventory, testing, } \\
\text { data recovery. } \\
\text { And assessment of } \\
\text { traditional cultural } \\
\text { properties. }\end{array}$ & 0 & 30,000 & 15,000 & 30,000 & $\begin{array}{l}\text { Incremental Increase- } \\
\text { Increasing the area of } \\
\text { potential effect offshore } \\
\text { would increase the } \\
\text { likelihood that } \\
\text { submerged cultural } \\
\text { resources would be found } \\
\text { requiring documentation } \\
\text { or mitigation. This } \\
\text { estimate assumes that } \\
\text { the nearshore footprint } \\
\text { of the cable landing is the } \\
\text { same at all project } \\
\text { phases. If nearshore or } \\
\text { shore-based footprint } \\
\text { were to grow, costs } \\
\text { would also grow. }\end{array}$ \\
\hline Navigation & $\begin{array}{l}\text { Assess } \\
\text { navigational use } \\
\text { of project area } \\
\text { and potential } \\
\text { effects caused by } \\
\text { project operation. } \\
\text { Also assess effects } \\
\text { to navigation if } \\
\text { project is } \\
\text { damaged by } \\
\text { debris. }\end{array}$ & 0 & 0 & 10,000 & 20,000 & $\begin{array}{c}\text { (Small Commercial) } \\
\text { Covered in Pilot-Pilot } \\
\text { costs } \$ 10 \mathrm{k}-15 \mathrm{k} \text {. Small } \\
\text { commercial, similar } \\
\text { footprint to pilot-scale, } \\
\text { pilot studies would be } \\
\text { applicable. } \\
\text { (large Commercial) } \\
\text { Incremental Increase- } \\
\text { larger footprint than pilot } \\
\text { and small commercial } \\
\text { may require additional } \\
\text { studies or data } \\
\text { processing. }\end{array}$ \\
\hline
\end{tabular}




\begin{tabular}{|c|c|c|c|c|c|c|}
\hline Recreation & $\begin{array}{l}\text { Additional } \\
\text { assessment costs } \\
\text { above pilot for } \\
\text { more precision, } \\
\text { focus groups or } \\
\text { panel evaluations, } \\
\text { survey based } \\
\text { evaluations, } \\
\text { descriptive use } \\
\text { information study, } \\
\text { evaluation of } \\
\text { changes to } \\
\text { recreational } \\
\text { resource }\end{array}$ & 125,000 & 375,000 & 125,000 & 375,000 & $\begin{array}{l}\text { Additive Studies-Larger } \\
\text { project area, greater } \\
\text { potential risk to } \\
\text { recreational } \\
\text { opportunities, may } \\
\text { require more detailed } \\
\text { and intensive studies to } \\
\text { understand potential } \\
\text { effect on recreational } \\
\text { resources and mitigation } \\
\text { strategies }\end{array}$ \\
\hline Total & & 770,000 & $1,555,000$ & 595,000 & $1,615,000$ & \\
\hline
\end{tabular}

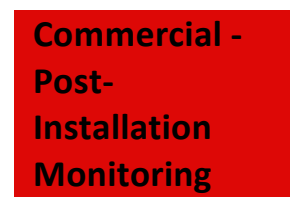

\begin{tabular}{|c|c|c|c|c|c|c|}
\hline $\begin{array}{c}\text { Informatio } \\
\mathrm{n} \text { Need }\end{array}$ & Specific Studies & 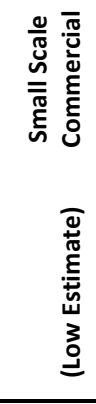 & 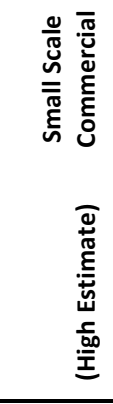 & 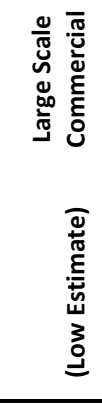 & 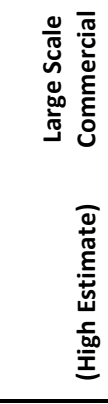 & $\begin{array}{c}\text { Scaling Rules-Scaling up } \\
\text { from pilot }\end{array}$ \\
\hline $\begin{array}{l}\text { Marine } \\
\text { Mammals } \\
\text { and Turtles }\end{array}$ & $\begin{array}{l}\text { Nearfield } \\
\text { Monitoring-Strike, } \\
\text { entanglement, } \\
\text { aggregation effects, } \\
\text { avoidance effects. }\end{array}$ & 30,000 & 325,000 & 30,000 & 325,000 & $\begin{array}{l}\text { Continuing Costs: } \\
\text { Monitoring at the pilot } \\
\text { scale will have } \\
\text { established effects at the } \\
\text { nearfield; costs for small } \\
\text { commercial nearfield } \\
\text { monitoring will be lower } \\
\text { or remain at the same } \\
\text { level per year. At the low } \\
\text { end of range, periodic } \\
\text { surveys expected. At the } \\
\text { high end, continuation of } \\
\text { nearfield visual and } \\
\text { acoustic monitoring } \\
\text { (farfield monitoring is an } \\
\text { additive study costed } \\
\text { below under "Ecosystem } \\
\text { Effects"). Costs are per } \\
\text { year-potentially } \\
\text { recurring for 2-3 years at } \\
\text { high costs, and } \\
\text { continuing at a lower } \\
\text { level of effort and cost for } \\
\text { the term of the license. }\end{array}$ \\
\hline
\end{tabular}




\begin{tabular}{|c|c|c|c|c|c|c|}
\hline Fish & $\begin{array}{l}\text { Nearfield } \\
\text { Monitoring-Strike, } \\
\text { aggregation effects, } \\
\text { avoidance effects. }\end{array}$ & 30,000 & 325,000 & 30,000 & 325,000 & $\begin{array}{l}\text { Continuing Costs: } \\
\text { Monitoring at the pilot } \\
\text { scale will have } \\
\text { established effects at the } \\
\text { nearfield; costs for small } \\
\text { commercial nearfield } \\
\text { monitoring will be lower } \\
\text { or remain at the same } \\
\text { level per year. At the low } \\
\text { end of range, periodic } \\
\text { surveys expected. At the } \\
\text { high end, continuation of } \\
\text { nearfield visual and } \\
\text { acoustic monitoring } \\
\text { (farfield monitoring is an } \\
\text { additive study costed } \\
\text { below under "Ecosystem } \\
\text { Effects"). Costs are per } \\
\text { year-potentially } \\
\text { recurring for } 2-3 \text { years at } \\
\text { high costs, and } \\
\text { continuing at a lower } \\
\text { level of effort and cost for } \\
\text { the term of the license. }\end{array}$ \\
\hline Seabirds & $\begin{array}{l}\text { Nearfield } \\
\text { Monitoring-Strike, } \\
\text { aggregation effects, } \\
\text { avoidance effects. }\end{array}$ & 30,000 & 150,000 & 30,000 & 150,000 & $\begin{array}{l}\text { Continuing Costs: } \\
\text { Monitoring at the pilot } \\
\text { scale will have } \\
\text { established effects at the } \\
\text { nearfield; costs for small } \\
\text { commercial nearfield } \\
\text { monitoring will be lower } \\
\text { or remain at the same } \\
\text { level per year. At the low } \\
\text { end of range, periodic } \\
\text { surveys expected. At the } \\
\text { high end, continuation of } \\
\text { nearfield visual and } \\
\text { acoustic monitoring } \\
\text { (farfield monitoring is an } \\
\text { additive study costed } \\
\text { below under "Ecosystem } \\
\text { Effects"). Costs are per } \\
\text { year-potentially } \\
\text { recurring for } 2-3 \text { years at } \\
\text { high costs, and } \\
\text { continuing at a lower } \\
\text { level of effort and cost for } \\
\text { the term of the license. }\end{array}$ \\
\hline Benthos & $\begin{array}{l}\text { Periodic survey and } \\
\text { sampling to } \\
\text { determine effects }\end{array}$ & 30,000 & 100,000 & 30,000 & 100,000 & $\begin{array}{l}\text { Continuing Costs: } \\
\text { Monitoring at the pilot } \\
\text { scale (if applicable) will } \\
\text { have established effects } \\
\text { at the nearfield; if } \\
\text { monitoring was carried } \\
\text { out at the pilot scale, } \\
\text { costs for small }\end{array}$ \\
\hline
\end{tabular}




\begin{tabular}{|c|c|c|c|c|c|c|}
\hline & & & & & & $\begin{array}{l}\text { commercial at the } \\
\text { nearfield will be smaller } \\
\text { or constant and may also } \\
\text { include sampling and } \\
\text { surveys of the farfield. At } \\
\text { the low end of range, } \\
\text { periodic nearfiled surveys } \\
\text { expected. At the high } \\
\text { end, additional sampling } \\
\text { may be required in the } \\
\text { farfield. Costs are per } \\
\text { year-potentially } \\
\text { recurring for } 2-3 \text { and } \\
\text { continuing at a lower } \\
\text { level of effort and cost for } \\
\text { the term of the license. }\end{array}$ \\
\hline $\begin{array}{l}\text { Noise and } \\
\text { EMF } \\
\text { Characteriz } \\
\text { ation } \\
\text { Monitoring }\end{array}$ & $\begin{array}{l}\text { Noise coming off } \\
\text { turbines and EMF } \\
\text { off turbines and } \\
\text { cables. }\end{array}$ & 20,000 & 20,000 & 20,000 & 20,000 & $\begin{array}{l}\text { Continuing Cost: } \\
\text { Assuming initial } \\
\text { investment and } \\
\text { deployment of } \\
\text { monitoring technology at } \\
\text { pilot scale, costs would } \\
\text { be only for the recurring } \\
\text { data collection and } \\
\text { analysis. Costs are per } \\
\text { year-potentially } \\
\text { recurring for } 2-3 \text { years at } \\
\text { high costs, and } \\
\text { continuing at a lower } \\
\text { level of effort and cost for } \\
\text { the term of the license. }\end{array}$ \\
\hline Navigation & $\begin{array}{l}\text { Develop signage } \\
\text { and lighting scheme } \\
\text { to warn boaters of } \\
\text { project presence- } \\
\text { monitor safety and } \\
\text { compliance }\end{array}$ & 40,000 & 40,000 & 40,000 & 40,000 & $\begin{array}{l}\text { Continuing Costs, } \\
\text { Incremental Increase- } \\
\text { Larger project footprint } \\
\text { may require purchase } \\
\text { and installation of } \\
\text { additional signage and } \\
\text { lighting, as well as } \\
\text { compliance monitoring. } \\
\text { Upfront cost, with } \\
\text { compliance monitoring } \\
\text { continuing for term of } \\
\text { license. }\end{array}$ \\
\hline
\end{tabular}




\begin{tabular}{|c|c|c|c|c|c|c|}
\hline $\begin{array}{l}\text { Ecosystem } \\
\text { Effects } \\
\text { Seabird }\end{array}$ & $\begin{array}{l}\text { Assess changes to } \\
\text { pre-installation } \\
\text { population analysis, } \\
\text { fitness, food } \\
\text { availability and } \\
\text { preference, } \\
\text { reproduction- } \\
\text { compare to existing } \\
\text { data (assuming } \\
\text { availability) }\end{array}$ & 200,000 & 500,000 & 200,000 & 300,000 & $\begin{array}{l}\text { Additive Study-If there } \\
\text { is regulatory concern that } \\
\text { the scale of a project is } \\
\text { likely to result in food } \\
\text { chain or ecosystem } \\
\text { effects on species of } \\
\text { concern, monitoring may } \\
\text { be required to assess } \\
\text { changes based on pre- } \\
\text { installation baseline } \\
\text { studies. Studies may not } \\
\text { be required for small- } \\
\text { scale commercial } \\
\text { deployments. If Before } \\
\text { After Control Impact } \\
\text { (BACl)-type studies are } \\
\text { required for large } \\
\text { commercial deployments, } \\
\text { cost could be very high } \\
\text { and have tremendous } \\
\text { effects on project } \\
\text { feasibility. Costs are per } \\
\text { year-potentially } \\
\text { recurring for } 3-5 \text { years at } \\
\text { high costs, and } \\
\text { continuing at a reduced } \\
\text { effort and cost for the } \\
\text { term of the license. Costs } \\
\text { may increase periodically } \\
\text { (approximately every five } \\
\text { years) for additional } \\
\text { survey effort or } \\
\text { equipment replacement. }\end{array}$ \\
\hline $\begin{array}{l}\text { Ecosystem } \\
\text { Effects } \\
\text { Marine } \\
\text { Mammals } \\
\text { and Turtles }\end{array}$ & $\begin{array}{l}\text { Assess changes to } \\
\text { pre-installation } \\
\text { population analysis, } \\
\text { fitness, food } \\
\text { availability and } \\
\text { preference, } \\
\text { reproduction- } \\
\text { compare to existing } \\
\text { data (assuming } \\
\text { availability) }\end{array}$ & 200,000 & 500,000 & 200,000 & 300,000 & $\begin{array}{l}\text { Additive Study-If there } \\
\text { is regulatory concern that } \\
\text { the scale of a project is } \\
\text { likely to result in food } \\
\text { chain or ecosystem } \\
\text { effects on species of } \\
\text { concern, monitoring may } \\
\text { be required to assess } \\
\text { changes based on pre- } \\
\text { installation baseline } \\
\text { studies. Studies may not } \\
\text { be required for small- } \\
\text { scale commercial } \\
\text { deployments. If Before } \\
\text { After Control Impact } \\
\text { (BACI)-type studies are } \\
\text { required for large } \\
\text { commercial deployments, } \\
\text { cost could be very high } \\
\text { and have tremendous } \\
\text { effects on project } \\
\text { feasibility. Costs are per } \\
\text { year-potentially } \\
\text { recurring for } 3-5 \text { years at } \\
\text { high cost, and continuing } \\
\text { at a reduced effort and } \\
\text { cost for the term of the } \\
\text { license. Costs may } \\
\text { increase periodically } \\
\text { (approximately every five } \\
\text { years) for additional } \\
\text { survey effort or } \\
\text { equipment replacement. }\end{array}$ \\
\hline
\end{tabular}




\begin{tabular}{|c|c|c|c|c|c|c|}
\hline $\begin{array}{l}\text { Ecosystem } \\
\text { Effects Fish }\end{array}$ & $\begin{array}{l}\text { Assess changes to } \\
\text { pre-installation } \\
\text { population analysis, } \\
\text { fitness, food } \\
\text { availability and } \\
\text { preference, } \\
\text { reproduction- } \\
\text { compare to existing } \\
\text { data (assuming } \\
\text { availability) }\end{array}$ & 200,000 & 500,000 & 200,000 & 300,000 & $\begin{array}{l}\text { Additive Study-If there } \\
\text { is regulatory concern that } \\
\text { the scale of a project is } \\
\text { likely to result in food } \\
\text { chain or ecosystem } \\
\text { effects on species of } \\
\text { concern, monitoring may } \\
\text { be required to assess } \\
\text { changes based on pre- } \\
\text { installation baseline } \\
\text { studies. Studies may not } \\
\text { be required for small- } \\
\text { scale commercial } \\
\text { deployments. If Before } \\
\text { After Control Impact } \\
\text { (BACl)-type studies are } \\
\text { required for large } \\
\text { commercial deployments, } \\
\text { cost could be very high } \\
\text { and have tremendous } \\
\text { effects on project } \\
\text { feasibility. Costs are per } \\
\text { year-potentially } \\
\text { recurring for } 3-5 \text { years at } \\
\text { high costs, and } \\
\text { continuing at a reduced } \\
\text { effort and cost for the } \\
\text { term of the license. Costs } \\
\text { may increase periodically } \\
\text { (approximately every five } \\
\text { years) for additional } \\
\text { survey effort or } \\
\text { equipment replacement. }\end{array}$ \\
\hline Total & & 780,000 & $\begin{array}{r}2,460,00 \\
0\end{array}$ & 780,000 & $1,860,000$ & (Per Year) \\
\hline $\begin{array}{l}\text { 30-year } \\
\text { total }\end{array}$ & & $7,750,000$ & $\begin{array}{r}14,580,0 \\
00\end{array}$ & $7,750,000$ & $\begin{array}{r}14,580,00 \\
0\end{array}$ & $\begin{array}{l}\text { (Based on cost profile } \\
\text { illustrated in chart } \\
\text { below) }\end{array}$ \\
\hline
\end{tabular}




\begin{tabular}{|c|c|c|c|c|c|c|c|}
\hline $\begin{array}{l}\text { Commercial - } \\
\text { NEPA and } \\
\text { Process }\end{array}$ & & & & & & & \\
\hline & $\begin{array}{l}\text { Information } \\
\text { Need }\end{array}$ & $\begin{array}{l}\text { Specific } \\
\text { Studies }\end{array}$ & 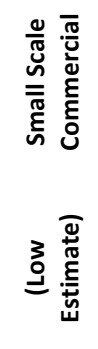 & 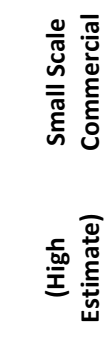 & 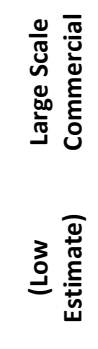 & 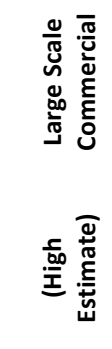 & $\begin{array}{l}\text { Scaling Rules-Scaling up } \\
\text { from pilot }\end{array}$ \\
\hline & $\begin{array}{l}\text { NEPA } \\
\text { Document } \\
\text { Preparation }\end{array}$ & $\begin{array}{l}\text { Consulting } \\
\text { firm } \\
\text { contract }\end{array}$ & 50,000 & 100,000 & 50,000 & 100,000 & $\begin{array}{l}\text { Incremental Increase- } \\
\text { NEPA document from pilot } \\
\text { project will inform } \\
\text { preparation of commercial } \\
\text { scale document. But longer } \\
\text { process, higher potential } \\
\text { for environmental effects, } \\
\text { and greater agency } \\
\text { scrutiny will likely require } \\
\text { additional work. }\end{array}$ \\
\hline & $\begin{array}{l}\text { Monitoring } \\
\text { and Study } \\
\text { Plans }\end{array}$ & $\begin{array}{l}\text { Consultants } \\
\text { or research } \\
\text { partners }\end{array}$ & 20,000 & 50,000 & 20,000 & 50,000 & $\begin{array}{l}\text { Incremental Increase- } \\
\text { Study plans from pilot } \\
\text { project will inform } \\
\text { preparation of commercial } \\
\text { scale document. Higher } \\
\text { potential for } \\
\text { environmental risk, and } \\
\text { greater agency scrutiny will } \\
\text { require additional study } \\
\text { plan preparation. }\end{array}$ \\
\hline & Total & & 70,000 & 150,000 & 70,000 & 150,000 & \\
\hline
\end{tabular}




\begin{tabular}{|c|c|c|c|c|c|c|}
\hline $\begin{array}{l}\text { Information } \\
\text { Need }\end{array}$ & $\begin{array}{l}\text { Specific } \\
\text { Studies }\end{array}$ & 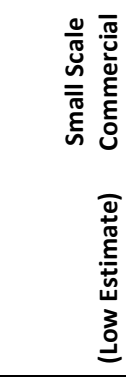 & 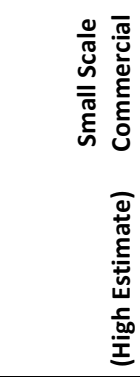 & 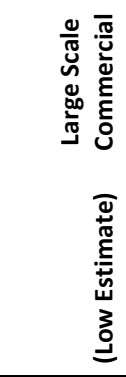 & 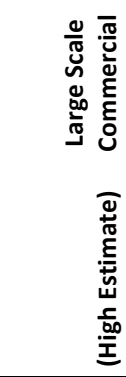 & Notes \\
\hline $\begin{array}{l}\text { Siting and } \\
\text { Scoping }\end{array}$ & & 67,000 & 105,000 & 77,000 & 105,000 & $\begin{array}{l}\text { Preliminary Permit, } \\
\text { scoping, and lead up to } \\
\text { DLA }\end{array}$ \\
\hline $\begin{array}{l}\text { Pre- } \\
\text { Installation } \\
\text { Studies }\end{array}$ & & 770,000 & $1,555,000$ & 595,000 & $1,615,000$ & $\begin{array}{c}\text { From final license } \\
\text { agreement through } \\
\text { baseline data collection } \\
\text { phase }\end{array}$ \\
\hline $\begin{array}{l}\text { Post- } \\
\text { Installation }\end{array}$ & & $7,750,000$ & $14,580,000$ & $7,750,000$ & $\begin{array}{r}14,580,00 \\
0\end{array}$ & $\begin{array}{c}\text { Over the course of the } 30 \\
\text { year license }\end{array}$ \\
\hline $\begin{array}{l}\text { NEPA and } \\
\text { Process }\end{array}$ & & 70,000 & 150,000 & 70,000 & 150,000 & $\begin{array}{l}\text { Over the course of the } \\
\text { FERC licensing process, } \\
\text { Preliminary permit to FLA }\end{array}$ \\
\hline Total & & $8,657,000$ & $16,390,000$ & $8,492,000$ & $\begin{array}{r}16,450,00 \\
0\end{array}$ & $\begin{array}{l}\text { (additional costs above } \\
\text { those incurred in pilot) }\end{array}$ \\
\hline
\end{tabular}




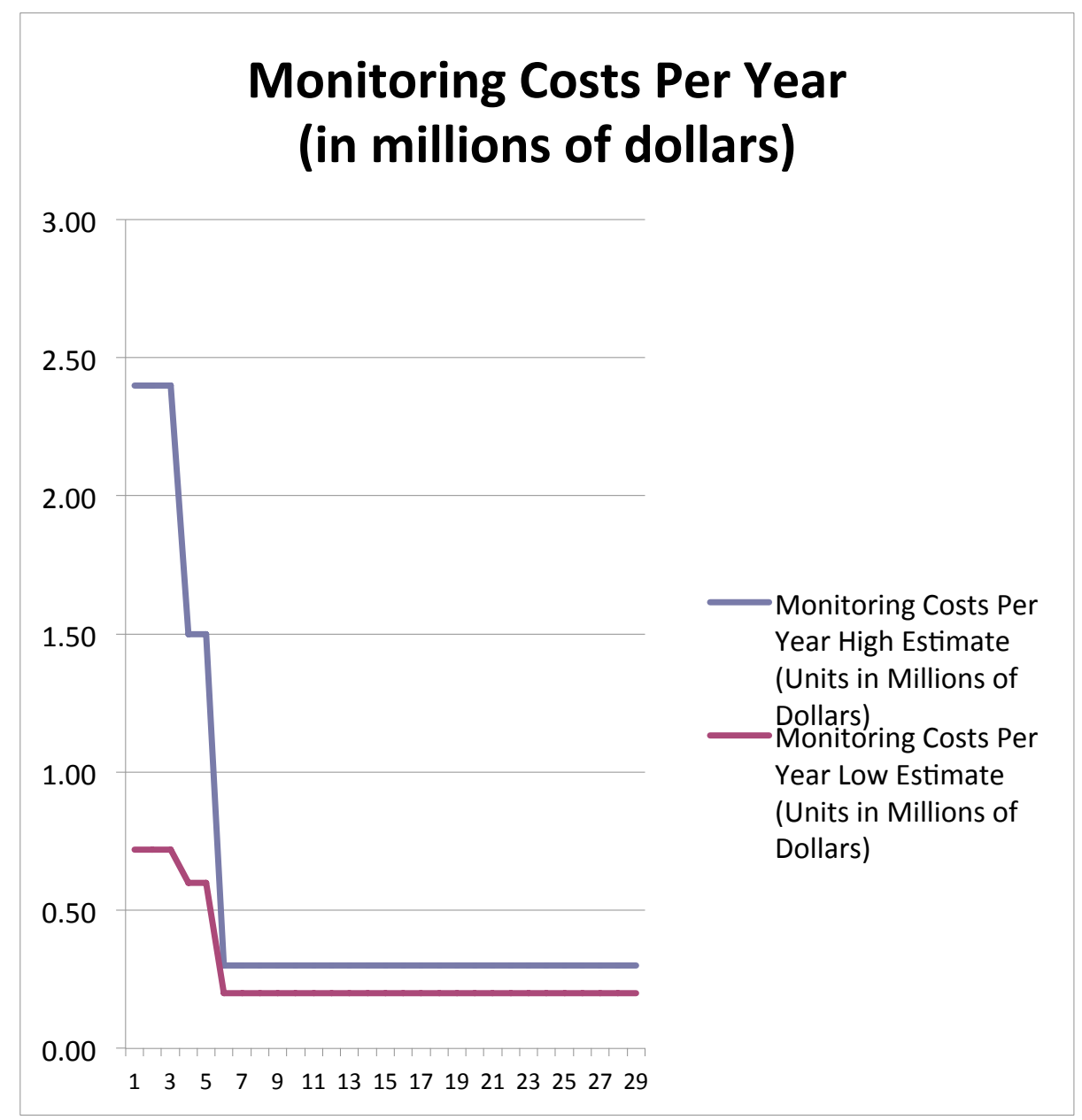

Monitoring Monitoring Costs Per Costs Per Year High Year Low Estimate Estimate (Units in (Units in Millions of Millions of Dollars) Dollars)

1.860 0.78

1.860 0.78

1.860 0.78

0.9 0.305 $0.9 \quad 0.305$

0.3

0.3

0.2

0.3

0.2

0.3

0.2

0.3

0.2

0.3

0.2

0.3

0.2

0.3

0.2

0.3

0.2

0.3

0.2

0.3

0.2

0.3

0.2

0.3

0.2

0.3

0.2

0.3

0.2

0.3

0.2

0.3

0.2

0.3

0.2

0.3

0.2

0.3

0.2

0.3

0.2

0.3

0.2

0.3

0.2

0.3

0.2 


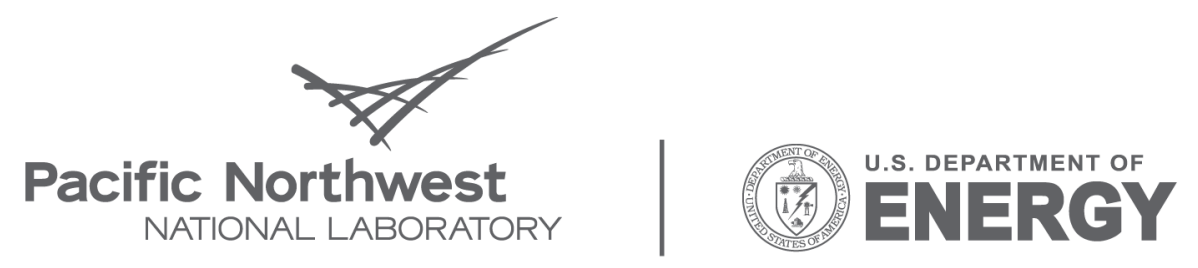

Proudly Operated by Battelle Since 1965

902 Battelle Boulevard

P.O. Box 999

Richland, WA 99352

1-888-375-PNNL (7665)

www.pnl.gov 